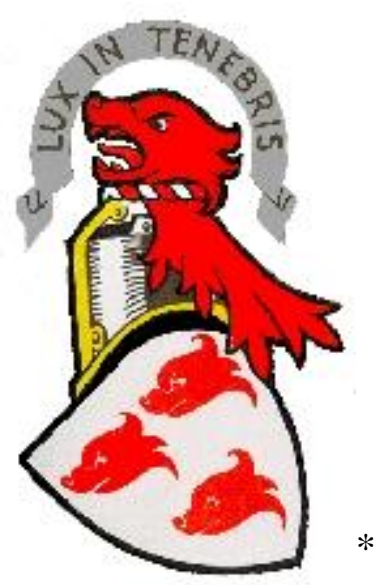

\title{
The Common Law and Taxation of Trusts in Australia in the Twenty-First Century
}

\author{
A Paper that examines the common law and taxation of trusts and the \\ practical application of these principles in the use of trusts as a tax- \\ planning vehicle \\ by \\ Alexander Robert (Lex) FULLARTON \\ M Com (Taxation \& Commercial Law) (Curtin); MTax (Curtin); \\ PGrad Dip Bus (Taxation) (Curtin); \\ Grad Cert Taxation (Curtin) \\ B Com (Taxation \& Commercial Law) (Curtin) \\ Dip Acct (TAFE); Dip Real Est Mgt (TAFE)
}

FTIA FNIA AREI AIMM CD

(C) A R Fullarton June 2001

Revised November 2006

This publication is copyright. Other than for the purposes of and subject to the conditions prescribed under the Copyright Act, no part of it may in any form or by any means (electronic, mechanical, microcopying, photocopying, recording or otherwise) be reproduced, stored in a retrieval system or transmitted without prior written permission. Inquiries should be addressed to the author.

\footnotetext{
${ }^{*}$ Fullarton Crest see endnote.
} 


\section{Contents}

1. Introduction 3

PART A. Common Law issues relating to Trusts

2. The purpose and history of Trusts 6

3. Equity and Fiduciary relationships 10

4. Types of Trusts and their methods of creation 14

5. Termination of Trusts 22

6. Implied and Constructive Trusts and Trust Accounting 25

PART B. Taxation Law issues relating to Trusts

7. Taxation of Trust Distributions 31

under Australian Income Taxation Law

8. Capital Gains Tax implications 33

9. Non-Resident Trusts 36

10. Stamp Duty and Land Tax issues 40

11. Personal exertion trusts and interposed entities 43

$\begin{array}{lll}\text { 12. } & \text { Future Legislation } & 47\end{array}$

13. Suggested Outcomes 51

14. Acknowledgements and References 58

$\begin{array}{ll}\text { 15. Endnote } & 60\end{array}$ 


\begin{abstract}
$\underline{\text { Abstract }}$
This paper proposes that the concept of the 'trust' held for over a thousand years under the British legal system is drawing to a close. Education and Legislation is heralding the demise of that ancient and noble institution in the Australian context. The Paper puts forward various alternatives and solutions to the identified problems.
\end{abstract}

The term 'trust' by definition expresses honour, reliance, justice and friendship. It implies an honourable relationship under which the property of one, the beneficiary, is placed in the control of another, the trustee. The Knights and Barons of Medieval England did not trust their descendants to manage their titles in a favourable fashion but suspected they would slowly but surely allow the decay of property that the barons had fought long and hard to establish. Various types of trust have come to be recognised in modern law.

In modern times the focus of trusts has shifted somewhat from the preservation of property to the alienation of income and hence taxation. Australian taxation law has continued to attempt to tax the income and property of these trusts with varying degrees of success. Series of Australian Governments have enacted and proposed legislation to pierce the trust structure and tax the income in the hands of the beneficiaries. Where the beneficiaries cannot be taxed the trustee is responsible for the tax.

For trading purposes trusts are no longer the optimum business structure. The previous taxation benefits of income splitting (and thereby reducing individual taxation burdens) are coming to an end. Trust income arising from personal exertion, whereby income earned by an individual is attempted to be transposed into earnings of a trust, has been vigorously attacked in recent years. The problem is that it is difficult to distinguish between a 'genuine purpose' and a 'tax avoidance one'.

As beneficiaries are becoming more legally aware they realise the property of their parents has been transferred to them. Parents are being faced with either having to relinquish ownership and control of 'their' property or admit that the structure is simply a means of avoiding tax. 


\section{Introduction.}

\section{"Behold men! I have England already in my grasp."}

(William I (the Conqueror) 1066 on falling from his longship onto the muddy flat, prior to the Battle of Hastings; King of England 1066-87, 1027-1087)

The term "trust" by definition expresses honour, reliance, justice and friendship. It implies an honourable relationship under which the property of one, the beneficiary, is placed in the control of another, the trustee. Arising from the days of William the Conqueror, trusts have been established largely from the desire to preserve the title of the medieval baron.

It is more a question of 'Don't Trust'. The Knights and Barons did not trust their descendants to manage their titles in a favourable fashion but rather suspected they would slowly but surely allow the decay of property that the barons had fought long and hard to establish. By removing control from their descendants and placing it in the hands of "trusted" persons, the Knights and Barons hoped to retain their titles intact despite the vagrancies of children.

Various types of trust have come to be recognised at law, yet all have the same final purpose, that is to allow the beneficiaries to enjoy and profit from the property but control to lay in the hands of a "trusted person." Australian taxation law has continued to attempt to tax the income and property of these trusts with varying degrees of success. In modern times the focus of trusts has shifted somewhat from the preservation of property to the alienation of income and hence taxation.

Series of Australian Governments have enacted and proposed legislation to pierce the trust structure and tax the income in the hands of the beneficiaries. In situations where the beneficiaries cannot be readily identified or ascertained, legislation has been placed to make the trustee responsible for the tax burden.

It is a matter of conjecture as to whether or not parliamentarians are serious in their attempts to tax the income of trusts as they themselves are quite often the beneficiaries of such trusts. Trust income arising from personal exertion, whereby income earned by an individual is attempted to be transposed into earnings of a trust, has been vigorously attacked in recent years.

The taxation of 'Interposed Entities' continues to be at the forefront of legislators minds. The problem is that without dissolving the original intention of the trust, that is to manage property, it is difficult, if not impossible, to distinguish between a 'genuine purpose' and a 'tax avoidance one'.

A serious failure of the taxation of trusts is that whilst income must be distributed to the beneficiaries of a trust, losses cannot be. Losses serve only to diminish the corpus or capital of the trust. There is not a benefit in loss-producing trusts to any entity. For trading purposes, therefore, trusts are not the optimum business structure. The previous taxation benefits of income splitting (and thereby reducing individual taxation burdens) are coming to an end. 
Further, as beneficiaries are becoming more aware, they are realising that the property has legally been divested by the original owner. Many instances where children are insisting on their legal right to the property exist. Parents are being faced with either having to relinquish ownership and control of 'their' property or admit that the structure is simply a means of avoiding tax and pay the consequences.

This paper proposes to demonstrate that the concept of the "trust" held for over a thousand years under the British legal system is drawing to a close. Education and legislation is heralding the demise of that ancient and noble institution in the Australian context and the paper concludes by putting forward various alternatives and solutions to the identified problems.

The structured of this paper is as follows;-

Part A, which focuses on the history and common law issues relating to the components of trusts, the relationships between the parties involved, types of trusts and their termination;

Part B, which examines the taxation implications and uses of trusts as tax planning vehicles; and

The conclusion which argues that political forces, particularly those concerned with taxation, will eventually force people using trusts to adopt some other corporate structure and abandon the establishment of trusts as tax planning vehicles.

The objective of this paper is to examine the concept of Trusts as part of the legal framework of ownership of property in our society. The Trust is a distinctly British institution though it has been adopted in other jurisdictions, chiefly the United States of America and parts of Latin America where the legal systems are based on civil law. The British Commonwealth of Nations, which is essentially comprised of ex-colonies or protectorates of Great Britain, has also adopted Trusts as part of their legal framework.

From their medieval origins Trusts have developed into an extremely diverse and complex means of property ownership and management. The legislation enabling and controlling Trusts, their beneficiaries and trustees is equally diverse and complex.

A Trust may be defined as a legal relationship created under the laws of equity whereby property (the corpus) is held by one party (the trustee), for the benefit of others (cestui que trust or beneficiaries).

The Trust is a uniquely British institution, descriptive of a relationship of legal ownership and use of property. The uniqueness is that the legal owner of the property does not, nor can not, benefit from the use of the property. Contrary to legal logic, the owner of the property (the trustee) is under an obligation to deal with the property exclusively in the interest of the beneficiaries, in accordance with the terms of the trust. The trustee is therefore estopped from benefiting in any way from his position as trustee of the trust. Any benefit arising deliberately or inadvertently to the trustee, becomes the property of the beneficiary and is termed a 'constructive trust'. 
The modern trust began its existence as the medieval English use:

In medieval England a landholder sometimes transferred the title to his land to another person who held it "to the use of" the transferor or of another. ${ }^{1}$

The duty was originally imposed as a moral obligation and was enforced as a matter of equity by the Court of Chancery which was a quasi-ecclesiastical court. 'In 1536 the English parliament enacted the Statute of Uses to put an end to the separation of legal and equitable estates. The statute "executed the use", that is, it turned the legal title over to the beneficiary. The courts held, however, that the statute applied only to certain interests in land, not to trusts of personal property, or to transfers in which the transferee was given duties to perform. ${ }^{2}$ Other deficiencies that caused the statute to be defeated were that if the owner (feoffee) ' . . . as a cestui que use has a beneficial interest in the land; and where there was a use on a use, . . . only the first use was executed by the statute. ${ }^{3}$ Thus the use evolved into the trust. ${ }^{4}$

The term 'trust' evolved to distinguish it from its predecessor the 'use'. Although the Statute of Uses was never repealed, the uses gave way to trust and by the end of the 17 th century trusts were an established part of asset protection and tax planning.

Just as the use gave way to the trust, the development of corporations and companies legislation in the 19th and 20th centuries has heralded the demise of the trust. Trusts however continue to be used as asset protection and tax planning vehicles into the 21 st Century. It is doubtful however that with changes to legislation and education of commerce and industry that they will continue in the 22nd century and that the 21 st century will be for the trust just as the 17th century was for the use.

\footnotetext{
${ }^{1}$ Collier's Encyclopaedia Vol 22 Macmillan Educational Company, New York, (1990) 500.

${ }^{2}$ Ibid.

${ }^{3}$ See Tyrells Case (1557) 2 Dyer 1552; 73 E.R. 336.

${ }^{4}$ Helen Hodgson, A Prospect Intelligence Report: Law and Taxation of Trusts (1996) 5.
} 


\section{PART A. Common Law issues relating to Trusts}

\section{The purpose and history of Trusts}

"Send in the archers!

Sire we have infantry in there!

Good point. Do we have reserves? Yes Sire. Good. Send in the Archers!"

(Edward I (Longshanks) 1296 at the Battle of Falkirk; King of England 1272-1307, 1239-1307)

The trust is embodied in British Law and owes its genesis to the Medieval Knights and their codes of conduct. The codes of conduct of the medieval knights were such that the concepts of fairness, justice and faith were ingrained into their learning, teaching and culture. Interestingly these codes did not extend to the favours of ladies. The nobleness of the Knight did not extend from the field of combat to the boudoir and many stories abound, fact or fiction, of the knights' sexual conduct.

The famed King Arthur, Lancelot and Genevieve may be fact or fable but the conduct was very real. The knights were disfavoured by the Christian Church and eventually persecuted by the same. One of the pretexts put forward by the Pope and his Cardinals for 'dealing with' the Knights Templar, was their lack of obedience to the sixth and ninth commandments.

In truth it was the Knights Templar immense fortunes and debts owed to them through their skilful and successful banking ventures that brought about their demise. ${ }^{5}$ The fortunes were too tempting for the evil King Philip (the fair) ${ }^{6}$ who plotted with the weak and foolish Pope Clement V, to destroy the noble knights and take their wealth.

Though successful in persecuting the Knights Templar, the fortune was never procured by the conspirators. 'When the King's agents visited the Templar treasury immediately after the first arrests, their great treasure, the very cause and objective of (the) brutal enterprise, had vanished without trace, as had almost the entire Templar Fleet. The King had been foiled. French Masonic ritual indicates that Scotland was designated as the place of refuge or safe keeping for the Templar treasures. ${ }^{7}$

Fact or fable, the codes of Knightly conduct of fairness and equity became embodied in British Law and British Law only.

As mentioned earlier the trust is a transfer of property from one party (settlor/testator (if by will)) to the use of another (trustee) for the benefit of yet another (beneficiary).

\footnotetext{
${ }^{5}$ European Templar Research Network A Brief History of the Knights Templar <http://www.euroknightstemplar.org/history.htm > at 15 ${ }^{\text {th }}$ May 200111.

${ }^{6}$ Philip le Bel (1268-1314), Philip V King of France.

${ }^{7}$ European Templar Research Network, above n 5.
} 
Trusts consist of four essential elements:-

1. Trust property - the corpus or body;

2. The Trustee - the person or entity in whom the corpus is entrusted;

3. Beneficiaries - the persons on whose behalf the property is managed, the owners; and

4. The Deed or instructions - the document which outlines the manner in which the trust property is to be dealt with on behalf of the beneficiaries. $^{8}$

These essential elements are required to carry out the purpose of the trust. The trust is not simply the transfer of property from one party to another in the legal sense as is a sale or a bequest. The transfer is subject to ongoing terms and conditions as to the administration of the property.

The ultimate transfer from the settlor to the beneficiaries cannot be prevented forever. The rule against perpetuities prevents indeterminable trusts. ${ }^{9}$ The ultimate transfer was not always the case. Prior to 1536 the Use was indeed indeterminable however it ' . . . became so popular as a tax (avoidance) device that in 1536 King Henry VIII passed the Statute of Uses ${ }^{10}$ which executed the use by conferring legal ownership on the person the use was intended to benefit. ${ }^{11}$

The Statute of Uses was unfortunately readily circumvented in that it only applied to real property, only passive uses were affected and active duties imposed on the owner of the property (feoffer) prevented to use from being executed, including the owner (feoffer) as a cestui que use (beneficiary) prevented execution and if there was a uses on the use i.e. A second trust, the first trust only could be executed. By ensuring the Statute of Uses was negated by including appropriate terms in the deed the execution could be circumvented.

The term Trust came into being to distinguish it from its predecessor. By the 17th Century it was easy to ensure trusts became enforceable and through the Statute of Uses (never repealed), the trust remained in use as a tax planning vehicle.

Its secondary, and indeed its initial, purpose of protecting and distributing family assets remain in place today. The development of corporations and family companies

\footnotetext{
${ }^{8}$ Robert L Deutsch et al., Australian Tax Handbook 2000 (2000), 1094 - 95.

9 The rule against perpetuities or 'the King's Life clause' is a law established by King Henry VIII, and adopted in statute by most jurisdictions which limits the life of a trust to eighty years. It is commonly termed the King's Life clause as it was determined that that was the lifespan of the King. Roderick P Meagher and W M C Gummow, Jacobs Law of Trusts in Australia (1997) 157.

${ }^{10}$ (1536) 27 Statutes 294.

${ }^{11}$ Hodgson, above $\mathrm{n} 4$.
} 
under respective national company laws is taking the place of trusts in modern commerce. The trust continues to be used for many reasons; protection of assets, charitable purposes, provision for family members, commercial ventures, for example Property Trusts, avoidance of certain statutes, - Inheritance Acts, Family Law Act 1957, Bankruptcy Act, and of course for tax planning.

Modern practises and anti-tax avoidance legislation as outlined later will eventually foreshadow the ultimate demise of trusts in Australia. They may however continue in other jurisdictions, particularly the developing ex-British colonies for many years as a tax avoidance vehicle and to isolate assets from creditors, governments and other parties interested in assets being the property of the settlor.

It must be noted that whilst the trustee holds the property of the trust for and on behalf of others, the beneficial ownership of a particular part of the trust is not necessarily that of specific beneficiaries. Several cases have rejected the concept that the beneficiary(ies) have a distinct and identifiable ownership of trust assets. ${ }^{12}$

It was held in Charles $v F C$ of $T^{13}$ 'that a unit holder in a unit trust had a "proprietary in all the property which for the time being is subject to the trust" ${ }^{14}$ [and] led the Victorian Supreme Court to say that a holder of a unit "in a unit trust" had "a proprietary interest in each of the assets which comprise the entirety of the trust fund". ${ }^{15}$

The cases of Glenn v Federal Commissioner of Land Tax $;{ }^{16}$ CPT Custodian Pty Ltd v CSR $(\text { Vic })^{17}$ and Halloran v Minister Administering National Parks \& Wildlife Act $1974^{18}$ reject that precept and found that there in fact may 'not be anyone who is the beneficial owner of the assets owned by the trustee. ${ }^{19}$ It is apparent that unless the trust is an extremely simple one, that is one asset with one beneficiary the clear link between the asset and its beneficial ownership may be difficult if not impossible to establish.

\footnotetext{
12 Commissioner of State Revenue v Lam \& Kym Pty Ltd [2004] VSCA 204; CPT Custodian Pty Ltd v CSR (Vic) [2005] HCA 53;[2005] ATC 4925; Glenn v Federal Commissioner of Land Tax (1915) 20 CLR 490; Halloran v Minister Administering National Parks \& Wildlife Act 1974 [2006] HCA 3.

13 (1954) 90 CLR 598.

14 Ibid, 609

15 John de Wijn, 'Trusts Revisited' (Paper presented at the Taxation Institute of Australia $14^{\text {th }}$ National Tax Intensive Retreat, Noosa, $23^{\text {rd }}$ November 2006) 6.

16 (1915) 20 CLR 490.

17 [2005] HCA 53;[2005] ATC 4925.

18 [2006] HCA 3.

19 John de Wijn, above n 15, 5 .
} 
Further it appears that unless the case of a simple trust with only one beneficiary exists as in the case of Baker $v$ Archer-Shee,${ }^{20}$ the dividends distributed by a trustee may not bear any relationship to the character of the profits to the trust. The change in character is particularly important to the treatment of trust profits for income tax purposes. Capital gains, primary production profits, dividend and foreign income are all treated differently to income according to ordinary concepts under the provisions of the Australian income tax assessment acts. The change in nature of the income may be critical to the treatment of the distribution in the hands of the benefiary.

Furthermore the establishment of the trust in Halloran was treated by the High Court as little more than a scheme to maximise land compensation from the Australian government. $^{21}$ It is suggested that trusts of a similar nature and purpose would fall victim to the general anti-taxation avoidance provisions of Part IVA of the Income Tax Assessment Act (1936).

${ }^{20}$ [1927] AC 844.

21 John de Wijn, above n 15, 29. 


\section{Equity and Fiduciary relationships}

". . . nothing in Law is so apt to mislead as a metaphor"

(Lord Mansfield, British Jurist, 1756 - 1793, 1705 -1793)

The concepts of equity and fiduciary are part of the code of chivalry. Equity is defined in the Webster's dictionary as ' . . . In Law, (a) resort to General Principles of fairness and justice whenever existing law is inadequate. ${ }^{22}$; and fiduciary, from the Latin fiduciarius, from fiducia, trust, a thing held in trust, from fidere, to trust. ${ }^{23}$ Trust itself is a medieval English word and is defined in Webster's as '. . . confidence; a reliance or resting of the mind on the integrity, veracity, justice, friendship, or other sound principle of another person or thing. 24

\section{A. Equity}

In British Law the courts of equity evolved from the sometimes unfair decisions handed down from the common law courts which dealt only with matters of law and where subject to strict protocols and procedures. It was not uncommon for a decision to be legally correct but morally wrong or unfair in its result. Examples put forward by Hodgson include:-

... if a debtor did not ensure that a bond was cancelled when a debt was paid out, the creditor could take action on the bond forcing a double payment. The common law viewed the resulting injustice as a result of the debtor's own folly; (or) . . . if an oral contract had been entered into and not reduced to writing, as there was no remedy available at common law on any breach of the terms of the contract. ${ }^{25}$

'These unfair results were a result not of the law itself, but the rigid system the law operated within. ${ }^{26}$ From the demand by petitioners to the King to rectify such unjust results the courts of equity or chancellor's court came to be established to hear and remedy the decisions of the common law courts.

The courts of equity were viewed not as superior courts to those of common law, but rather with the function to remedy imperfections of the common law. Where decisions in equity conflicted with those of common law, equity prevailed - not as a matter of rank but as a matter of fairness. Until 1873 with the enactment of the Judicature Acts (U.K.) 1873 and 1875, the courts where held as separate jurisdictions which lead to considerable inefficiencies in the legal system. By combining the power of the one court to hear matters of common law but also to apply an equitable remedy, the judges are given both powers to issue not only legally correct remedies but also to ensure

\footnotetext{
${ }^{22}$ Webster's New Twentieth Century Dictionary of the English Language unabridged $2^{\text {nd }}$ ed. (1956) 618

23 Ibid, 681.

24 Ibid, 1963

25 Hodgson, above n 4, 1.

26 Ibid
} 
they are fair remedies under the rules of equity. Australia inherited it laws from Britain as a series of British colonies. With the exception of South Australia, which never separated the two courts, the Australian states have enacted similar legislation to ' . . [combine] the jurisdictions following the United Kingdom ${ }^{27}$ model. ${ }^{, 28}$

In order to understand the concept of trusts, it is critical ot have a sound knowledge of equity and the courts of equity, as trusts owe their existence not to the common law but the principles of equity. 'At common law legal ownership is the only ownership recognised, whereas at equity it may be recognised that another person has an interest in the property and that should be protected. 29

The beneficiaries of an estate therefore do not have a legal interest in the estate, that legal interest is held by the trustee, they do however hold an equitable interest. As equity overrides common law the beneficiary's interest is enforceable over the trustee's interest as a matter of equity. There are some circumstances where the courts will not overturn the transfer of a legal title in favour of the equitable title.

The transfer of land in Western Australia could be transferred by the legal owner (trustee) without recognising the equitable title (beneficiaries) as the Transfer of Land Act (1893)(W.A.) ${ }^{30}$ prohibits the equitable owner from being registered on the title, even though it provides that a document evidencing ownership may be lodged separately with the Registrar for safe custody and reference.

Should the trustee so transfer a parcel of land the court will not cancel the transfer but '. . . will act in personam to compensate the owner of the equitable interest for the loss of the property. ${ }^{31}$ In that event the equitable interest will be defeated but the beneficiaries will be compensated for their loss. The trustee will have acted on his own behalf and not for the benefit of the beneficiaries he will be in breach of his fiduciary duty.

\section{B. Fiduciary Duty}

The key to trusts - is trust. Without trust, that is to act in good faith or ' . . a reliance or resting of the mind on the integrity, veracity, justice, friendship . . .32 the entire concept and purpose of the trust ceases to exist and the beneficiaries will not benefit from the property. The transfer of the property will in fact take place, not to the beneficiaries, as is the intention of the settlor, but rather to the trustee himself. The beneficiary(ies) will be defrauded of his(their) equitable interest.

\footnotetext{
27 For example, the judicature system was introduced in Western Australia by the Judicature Act (WA) 1880 .

${ }^{28}$ Hodgson, above n 4, 2.

29 Ibid, 3.

${ }^{30}$ Western Australia Sec 55 Transfer of Land Act 1873-1972.

31 Hodgson, above n 4, 3.

${ }^{32}$ Webster's, above n 12.
} 
Given that trusts owe their existence to a document, not recognised at common law and enforceable only by a court of equity, albeit one and the same in modern times in Australia, it is a relatively simple act for the trustee to divest the beneficiaries of their interest.

Transfers of property are carried out by him(her) without the knowledge or advice to either the purchaser or the beneficiaries. Furthermore legislation such as the Transfer of Land Act (1893)(W.A.), actually encourages the concealment of the trust. 'The courts have imposed a special duty, known as the fiduciary duty, where the relationship between the parties is such that the courts consider that such protection is necessary. ${ }^{33}$

There are many commercial and private arrangements that do involve some degree of fiduciary obligation, for example a director owes a duty to the company, ${ }^{34}$ an agent to a principal. ${ }^{35}$ This relationship is based on the special position of the parties where it cannot be said that the parties are dealing on an equal footing. The extent of the fiduciary duty owed will be determined by the court, based on the facts of the particular case. A fiduciary obligation will only be breached where there is a conflict of interest, whether actual or a significant possibility, between interest and fiduciary duty. ${ }^{36}$

The fiduciary is accountable to the principal for any benefit that accrues to the fiduciary as a consequence of a breach of the fiduciary duty. This doctrine was set out in Keech v. Sandford ${ }^{37}$. In that instance a trustee was unable to renew a lease to a trust, so (he) renewed the lease in his own name. It was held that the trustee held the lease on trust for the beneficiary of the trust. Lord Chancellor King held that the doctrine of accountability was so strict that it was better to allow the lease to run out than to allow the trustee to profit personally.

The trustee of a trust owes the highest degree of fiduciary duty to the beneficiaries, in relation to matters pertaining to the trust. The duty can be classified as follows:

When using the discretion of the office of trustee, the trustee:

(i) must not delegate the discretion;

(ii) must not act under another's discretion;

(iii) must not place fetters on the discretion; and

(iv) must consider whether to exercise the discretion.

In exercising the discretion the trustee:

(i) must not act for personal or a third party's benefit;

\footnotetext{
${ }^{33}$ Hodgson, above $\mathrm{n} 4$.

${ }^{34}$ Aberdeen Railway Co. v Blaikie Bros (1843-60) All E.R. 249.

35 Bannister v Bannister [1948] 2 All E.R. 133.

${ }^{36}$ Chan v Zacharia (1984) 154 C.L.R. 178

37 (1716) Sel Cas. T King 61: 25 E.R. 223. See Also Chan v Zacharia, supra.
} 
(ii) must treat beneficiaries with equal rights equally;

(iii) must treat beneficiaries with different rights fairly; and

(iv) must not act capriciously or unreasonably. ${ }^{38}$

${ }^{38}$ Hodgson, above n 4, 4. 


\section{Types of Trusts and their methods of creation}

"Put your trust in the Lord and keep your powder dry"

(Oliver Cromwell 1645 at the Battle of Naseby; Lord Protector of the Commonwealth of England, Scotland and Ireland 1655 - 1658, 1599 -1658)

Trusts may be broadly classified into three categories:-

(i) Express trusts;

(ii) Implied trusts; and

(iii) Constructive trusts:

The classifications are not simply for academic or study purposes. They are often required as part of the due process of law. The trusts classification may be required in order to prove the existence of the trust, and/or to ensure the intentions of the settlor are followed, as well as providing a legal basis for determining disputes should they arise.

The category into which each trust will fall is determined by classification according to four points of view.

(1) From the point of view of intent to create a trust. Here, trusts are either -
(a) express or declared; or
(b) presumed or implied; or
(c) constructive.

(2) From the point of view of the objects of the trust. Here, trusts are either -
(a) private; or
(b) public or charitable.

(3) From the point of view of the nature of the duties imposed upon the trustee. Here, trusts are either -
(a) simple; or
(b) special.

(4) From the point of view of the form of the declaration of trust. Here, trusts are either -
(a) executed; or
(b) executory. ${ }^{39}$

\footnotetext{
39 Meagher and Gummow, above n 9,63.
} 


\section{Express or Declared Trusts}

This classification is self explanatory in that the trust has been established by the settlor in express terms. The trustee may be instructed as to his duties and obligation orally, which can cause subsequent problems due to a lack of proof evidencing the existence of the trust and/or the details of the duties of the trustee. The lack of proof can lead to the conclusion that the trust does not in fact exist. ${ }^{40}$

The express intent to create, duties of the trustee and trust property or corpus is usually contained in a document termed the trust deed. By reducing the declaration to writing, this overcomes the doubt as to the existence and other problems that may arise due to lack of evidence.

\section{Presumed or Implied Trusts}

In the event that the trust has not been specifically declared by the creator or lack of evidence by way of deed or conduct of the parties to support an orally declared trust, a trust may exist by implication or presumption. The law makes a presumption that a trust exists from the circumstances of the case and '. . . that a trust was intended, notwithstanding the absence of language expressive of such an intention. ${ }^{41}$

Implied trusts may arise where an express trust is detailed in a vague or convoluted manner, however the conduct of the parties indicates to the court that a trust, though specifically un-evidenced, exists. An express trust created by a will may omit specific property but it is implied the creator intended all of his possessions or property be transferred to his beneficiaries. In such case the implied trust is referred to as a resultant trust.

'The term is also used to mean 'presumed by the court as a matter of law', that is, the court presumes that the intentions of the parties were to create the particular although there is no expression whatever of intention to be found. ${ }^{42}$

\section{Constructive Trusts}

The term is not at all used in the usual context, either by literal or legal meaning of the word 'constructive'. A constructive trust is one that is imposed or created by the court in order to correct a void that would otherwise exist in the circumstances wherein a person benefits from the use of property to which he is not lawfully entitled to use.

The constructive trust imposes the duties and obligations of a trustee '. . . upon the person who has control of the property (of another) although there has been no actual

\footnotetext{
40 Ibid, 64.

${ }^{41}$ See, eg, James $v$ Holmes (1862) 4 De G F \& J 470; 45 ER 1266.

${ }^{42}$ Meagher and Gummow, above n 9, 65.
} 
trust intended by the parties. ${ }^{43}$ The property may have fallen into the control of another, accidentally, by theft, deception or fraud. The intention is to prevent the person from benefiting by way of gain through the use of the property even though the actual property it self is returned to it rightful or intended owners. An example could be that of a trustee benefiting from unauthorised use of trust property.

Though the property is transferred to the beneficiaries within the terms of the trust, and they are not aware of the conversion of earnings, the earnings arising are deemed to be the property of the beneficiaries. The court imposes the obligations of a trustee as to the remainder of the property by way of a trust constructed by the court for the purpose of encompassing the secret property.

The terms and conditions that establish an express trust allow for innumerable variations. The settlor, in detailing the rights, duties and obligations of the trustee and beneficiaries in the trust deed, is limited only by the English language, his imagination and certain legal constraints such as legality of purpose and certainty.

The wide ranging possibilities of trust structures has allowed for many variances to be applied to trading trusts in the modern commercial world, some common trusts are outlined below.

\section{Unit Trusts}

A commercial enterprise, this is similar to a corporate structure under the respective company's legislation of various jurisdictions. The key differences between a unit trust and a registered company are the methods by which they are established and managed and the legislation and legal requirements governing their operation and accountability.

The structure, administration and statutory requirements governing registered companies is outside the scope of this examination and separate reference should be made to the relevant companies legislation to examine those requirements. Therefore the structure of unit trusts will be examined here.

The operation is basically that a settlor, usually a registered private company for limiting liability responsibilities to the individuals concerned, purchases property. The property is then vested in a trustee, usually another company set up for that purpose. Once again the protection afforded by limited liability is the chief purpose of the incorporated trustee. The value of the property is then divided into a large number of small sections called units.

The division is much the same as the division of capital in a company into shares. The units are then sold to the public at a market price reflecting the asset support for the unit plus a margin for administrative expenses. The conditions regulating the sale of units are not as stringent as the legislation relating to the sale of shares in companies to the public. The units may be on-sold at a price which reflects the increase in value of property owned by the trust or additional units created if additional property

\footnotetext{
43 Ibid.
} 
acquired. They may even be listed on the stock exchange subject to meet the stock exchange rules and regulation.

The units function in a similar way to shares in that income or profit is distributed based on the number of units held. There are however key differences between unitholders, partners and shareholders. Unit holders are entitled to an equitable share in the property of the trust as beneficiaries. Shareholders merely have the value of the par value of the share.

The ownership is of the share not the company property. Shareholders elect a board of directors to manage the company. Unit holders usually have no input as to the management of the trust. Partners are liable jointly and severally and take part in carrying on a business. Unit holders are not partners and have no obligations between each other. This view '. . . was upheld by the Court of Appeal in Smith v Anderson ${ }^{44}$. . ${ }^{45}$

The unit trust has existed since the nineteenth century and enjoyed considerable popularity as a commercial structure. The advent of companies' legislation particularly in Australia since the 1980s has produced a marked decline in public unit trusts as shareholders generally accept the protection of the public monies through the controls of companies listed on the stock exchange. Even those stringent requirements have not always protected investors from unscrupulous directors, though justice is usually at least seen to prevail.

The scandals of Alan Bond, Laurie Connell and Christopher Skase continue to cast doubt as to the effectiveness of legislation and the Law but nonetheless public shareholding is generally becoming preferred to holding units in unit trusts.

Generally however '. . . from as investor's point of view, for commercial purposes, owning units in a unit trust is the same as owning shares in a company. Legally, however, this is not so. As the High Court of Australia pointed out in Charles $v$ Federal Commissioner of Taxation: ${ }^{46}$

A unit held under this deed is fundamentally different from a share in a company. A share confers upon the holder no legal or equitable interest in the assets of the company; it is separate piece of property . . . . But a unit in the trust deed before us confers a proprietary interest in all the property which for the time being is subject to the trusts of the deed. ${ }^{, 47}$

The unit trust continues to have a role in modern commercial enterprise as the factor of proprietary interest may be significant for reasons other than pure investment. Many enterprises are being raised for the purposes of afforestation. Tea tree oil plantations, paulownia, blue gum and other like activities are being heavily promoted.

\footnotetext{
${ }^{44}$ (1880) 15 Ch D 247.

45 Meagher and Gummow, above n 9, 66.

46 (1954) 90 CLR 598 at 609.

47 Meagher and Gummow, above n 9, 67.
} 
Some of these enterprises are no more than scams to attract investors to invest their money in 'get rich quick schemes' which the promoters simply purloin.

Others are genuine attempts to reduce the effect of logging of old growth forests, to provide alternative timber sources for the future or simply ecologically responsible. Whatever the objective, these projects receive great scrutiny from the Australia Taxation Office. One of the key elements is to provide tax minimising benefits to the investors. Due to the reasons given in Charles v Federal Commissioner of Taxation ${ }^{48}$, the taxation benefits available to primary producers could not flow to shareholders, however they can flow to unit holders.

The days of the public unit trust may not be over yet as they may continue to have a role in tax planning, (see later discussion).

\section{Discretionary Trusts}

The entitlements of beneficiaries or classes of beneficiaries may be varied from time to time at the absolute discretion of the trustee. These rights may be as to distribution of income, rights to the use of property or such other rights as may be prescribed by the trust deed. The discretionary powers given to the trustee form a key element in the functioning of the operations of a 'Blind Trust' mentioned under.

\section{Bare Trusts}

Once the duties of the trustee have been completed and no further active duties are required of him, other than he continues to be the legal owner of the trust property, the trust has reached a point where it is referred to as a 'bare trust'. Essentially the trust property is awaiting its final transfer to the beneficiaries. It is a final and temporary position of the trust. ${ }^{49}$

\section{Trading Trusts}

A trading trust is a trust ' . . in which the trust property is the assets of a business being carried on for the benefit of the beneficiaries. These may be either fixed or discretionary trusts. ${ }^{50}$ Family trusts often become trading trusts. Generally this form of trust is used to minimise taxation by availing the use of individual tax rates being applied to income rather than company tax rates.

The reduction of company taxation rates and double tax relief by way of franking of dividends as outlined later is reducing the appeal of the trading trust as a commercial structure and tax planning vehicle.

\footnotetext{
48 (1954) 90 CLR 598 at 609.

49 Herdegen v Federal Commissioner of Taxation (1988) 84 ALR 271 at 281-2. see also Corin v Patton (1990) 169 CLR 540 at 579.

${ }^{50}$ Hodgson, above n 4, 49.
} 


\section{Blind Trusts}

Discussed later under the heading of 'Non-Resident Trusts' and used primarily as a vehicle for tax, and other debt, avoidance, the blind trust is more accurately defined as 'a discretionary trust with undisclosed beneficiaries'. The terms of the deed include ' ... an obligation ... imposed on the trustee to keep secret from his cestui que trust all (or some) details of the state of the trust's investments and of their value. ${ }^{51}$ The Blind Trust prevents the beneficiary, and hence any other person or party, from assessing the true wealth of the beneficiary.

\section{Service Trusts}

Trust established to administer professional offices such as lawyers, accountants or medical practitioners. The purpose being that the processes of record keeping, accounting, office and staff management are carried out by clerical staff thus permitting the professional to focus on the demands of his/her profession without the demands and responsibilities of administration and accounting.

In a number of professions association is limited to members of the same qualification, registration or membership of professional body. It is not uncommon for partners to be family members such as husband and wife or father and son. However frequently family members are not professional compatriots. In such cases income splitting by way of a partnership is not permitted by the profession or the law.

Service trusts become a tax planning vehicle by which non-qualified family members partake in profits of the profession. The service trust invoices the professional organisation for the administrative duties carried out by the clerical and administrative staff and resources supporting that organisation.

The sums that are charged by the service trust for the resources and services provided can result in a profit to the service trust. That profit is then distributed to the beneficiaries of the trust, often family members of the professionals involved in the practice. It is a vehicle by which professional incomes can be distributed to other taxpayers not otherwise qualified to partake in those profits.

Service trusts have attracted the attention of the Australian Taxation Office which often considers the structures to be tax avoidance schemes. In an address by the Commissioner of Taxation in $2003^{52}$ signalled that the ATO was concerned 'about some of the service trust arrangements employed by some professional practices.'

Whilst recognising the findings of the Phillips ${ }^{53}$ case the ATO remained critical of the commercial reality of the service trusts and the transfer of profits from the

\footnotetext{
51 Meagher and Gummow, above n 9, 70.

52 Michael Carmody, 'Future Directions in Tax Administration (A Relationship of Mutual Dependency)' (Speech delivered at the National Institute of Accountants, WA division, Perth, 17 June 2003)

53 Federal Commissioner of Taxation v. Phillips (1978) 78 ATC 436
} 
professional practice to other taxpayers not engaged in the organisation. The Commissioner stated that -

Very broadly, these features [of the service trust] include arrangements that are not established on an arms length basis, commercially unrealistic charge out fees and control and other arrangements seemingly more concerned with increasing the flexibility to distribute income to family members than with operating a commercial service business. ${ }^{54}$

There appears to be a fine line between a genuine commercial service trust and a tax avoidance scheme. Each case should be considered on the facts of the structure and type of organisation, its charges and comparative commercial reality.

\section{Charitable Trusts}

Distinctly different from any other kind of trust and worthy of examination far greater than this paper can provide in its current scope, charitable trusts are trusts set up for purposes not persons. Charitable trusts are not subject to the King's Life Clause and are therefore not limited in their term. The beneficiaries may include a class of persons, an organisation or institution.

The '... Statute of Charitable Uses $1601^{55}$. . . listed a number of charitable objects. If the objects of the trust are among those mentioned, or would be within the spirit and intention of that statute the court will consider it to be a charitable trust. These can be divided into the following categories: ${ }^{56}$

(i) trusts for the relief of poverty;

(ii) the advancement of education;

(iii) the advancement of religion;

(iv) other purposes beneficial to the public, including "within the spirit of the Charitable Uses Act 1601", benevolent purposes, hospitality or political purposes; and

(v) facilities for recreation or other leisure -time occupation, provided it is in the interests of social welfare, are specifically provided for by statute. $^{, 57}$

As with other forms of trust the structures and purposes of charitable trusts are as varied as the human imagination can provide. Many forms and structures are subject to special legislation as may be prescribed for time to time and from jurisdiction to jurisdiction, however the examination of the variances is beyond the scope of this paper, though it is as well as to know they exist.

\footnotetext{
${ }^{54}$ Carmody, above n 42.

5543 Eliz 1, c.4.

56 Income Tax Special Commissioners v Pensel [1891] A.C. 531.

57 Hodgson, above n 4, 20.
} 
There are many other variations to trusts, superannuation funds, family trusts but these variations are also outside the scope of this paper and accordingly not considered further here. 


\section{Termination of Trusts}

"I don't think the Prime Minister of a country should drink, do you?"

(John Winston Howard 1997 at St Andrew's in Scotland when asked what he thought of Scotland's fine Scotch Whiskey; Prime Minister of Australia1996 - , 1939 - )

The nature of the trust provides for its own demise. The transfer of management to the trustee is of a temporary nature as eventually the property must vest in the beneficiaries. The knights of medieval times may not have trusted their heirs and successors to effectively administer the estates they acquired, but ultimately those estates could not be deprived from them forever and legally had to be transferred to them. The trust can only hold off the inevitable - not prevent it forever.

This ultimate transfer is known as 'the rule against perpetuities': '. . . common law rules have been developed to ensure that the trust property vests in the beneficiaries within a reasonable period of time. This is incorporated in the trust deed, usually as being eighty years or the "King's Life Clause". ${ }^{58}$

The accuracy of the term, the rule against perpetuities, has been challenged in modern times, ${ }^{59}$, and ' . . has been abolished in New South Wales, Victoria, Queensland and Western Australia. ${ }^{60}$ The statutes in those States have replaced the rule against perpetuities but in doing so actually uphold the common law rule by replacing it with statute to the same effect.

An example of the replacement is the Property Law Act 1969 (WA) in which s 114 states 'The rule of law prohibiting the limitation after a life interest to an unborn person .... is hereby abolished, but without prejudice to any other rule relating to perpetuities.' The perpetuity period is then set by s 101 as to be ' . . such period of years not exceeding 80 as may be specified in the instrument creating that limitation or, if no such period of years is specified, that period that is applicable under the rule of law.'

The consequences of statutory replacement ultimately ensures the property of the trust vests in the beneficiary(ies) within a maximum of 80 years. The succession of beneficiaries ad infinitum is thus prevented. In any event s 101 of the Property Law Act (WA) limits the perpetuity period to eighty years. The aforementioned States have similar statutory provisions. ${ }^{61}$

These statutory provisions are required, given the flexibility of express trusts to place an indeterminable number of clauses in the trust deed to include methods and schemes

\footnotetext{
58 Ibid, 49.

59 Whitby $v$ Mitchell (1890) 44 ch D 85.

${ }^{60}$ See Conveyancing Act 1919 (NSW) s 23A; Perpetuities and Accumulations Act 1968 (Vic) s 12; Property Law Act 1974 (Qld) s 216; Property Law Act 1969 (WA) s 114.

61 Perpetuities Act 1984 (NSW) s 7; Perpetuities and Accumulations Act 1968 (Vic) s 5; Property Law Act (Qld) s 209.
} 
laid out to avoid the perpetuity of trust rules and statute, to act to prevent those avoidance clauses.

A trust therefore terminates at the point where the vesting date arrives and the property is vested in the beneficiary(ies).

In the event that a sole beneficiary remains and the trustee no longer has active duties to perform, '. . . a beneficiary that is sui juris, or of full legal age and capacity, and absolutely entitled, may demand possession of the trust property. ${ }^{, 62}$ Furthermore " The rule in Saunders $v$ Vautier ${ }^{63}$ provides that where a sole beneficiary with a vested interest in the trust property is sui juris, the beneficiary may direct the trustee to transfer the trust property to the beneficiary or a nominee, notwithstanding any direction to the contrary in the trust instrument. ${ }^{64}$

The vesting date may therefore arrive as determined by the deed, or it may be determined by order of the Court, in the event the sole beneficiary applies the rule in Saunders $v$ Vautier at an earlier date.

The settlor may terminate the trust by way of authority contained in the deed. The settlor may also apply to the Court to revoke the deed if such authority is not contained within the deed. The conditions under which the Court is likely to grant such revocation are so onerous that such application is unlikely to succeed. ${ }^{65}$

The trustee, if empowered by the deed, may terminate the trust and distribute the property to the beneficiaries. Where termination is not expressed the trustee may apply to the Court to terminate the trust.

In the event the settlor becomes the sole beneficiary, the trust is terminated by operation of the law.

A trust is also void if it lacks legality of purpose that is set up for some immoral, illegal or fraudulent purpose. In such case the trust is not terminated as in other cases, but rather rendered void and set aside as though it never existed. Interestingly, the law of trusts departs from the law of contract on the recovery of property by the wronged party. Whereas the law of contract provides that a contract entered into through fraud or some other illegality of purpose, is to be set aside as though it never existed, and the property returned to the position of ownership prior to the contract, the law of trusts does not: '. . . if the property is handed over to the beneficiary, and

\footnotetext{
${ }^{62}$ Hodgson, above n 4, 43.

${ }^{63}$ (1841) 49 E.R. 282.

${ }^{64}$ Hodgson, above n 4, 43.

65 Dutton v Thompson (1883) 23 Ch D 278; Henry v Armstrong (1881) 18 Ch D 668; Hall v Hall (1873) LR 8Ch App 430.
} 
the beneficiary not do what is required of him, the settlor will not be assisted by the courts to get his property back. ${ }^{, 66}$

The trustee is obliged to keep formal accounts to be presented to the beneficiary(ies) on demand and may demand evidence of handing over of the property to beneficiaries. When winding up he must take into account the rights of trust creditors and may demand indemnity against third parties where the deed provides for such or in certain limited circumstances. ${ }^{67}$ 'When vesting the trust the trustee must provide for all liabilities. 'When winding up a trading trust, the trustee and trust creditors, through the rights of indemnity and subrogation respectively, take preference over the trust beneficiaries. ${ }^{68}$

\footnotetext{
${ }^{66}$ Cottington v Fletcher (1740) 2 Atk 155, 24 ER 498; Muckleston v Brown (1801) 6 Ves 68, 31 ER 934; Brackenbury v Brackenbury (1820) 2 J \& W 37 ER 391; Groves v Groves (1829) 3 Y Jer 163, 148 ER 1136; Re Emery's Investments Trusts; Emery v Emery [1959] Ch 410 (contravention of foreign revenue law).

${ }^{67}$ Hodgson, above n 4, 52.

${ }^{68}$ Octavo Investments Pty Ltd v Knight (1979) 144 C.L.R. 360.
} 


\section{Implied and Constructive Trusts and Trust Accounting}

"I did but see her passing by, and yet I'll Love her till I die."

(Sir Robert Gordon Menzies 1963 when referring to Queen Elizabeth II's 1963 Australian Royal Visit; Prime Minister of Australia 1939 - 1941 and 1949 - 1966,

$1894-1978)$

Presumed or Implied Trusts and Constructive Trusts have been outlined under the heading of 'Types of Trusts and their methods of creation'. They are further examined here along with the record keeping requirements of a trust administrator.

\section{Implied Trusts}

As stated under the heading of 'Types of Trusts and their methods of creation', an implied trust is a trust created or presumed as a matter of the operation of the law, in circumstances where the deed of an express trust fails to cover all or some of the trust property or is vague or absent entirely.

In the case where the deed fails to cover all property the excess is treated by law as being trust property. The undescribed property therefore becomes a trust as a result of operation of the law. Implied trusts of this type are often referred to as 'resultant trusts' to further distinguish them from trusts established by the conduct of the parties and where written evidence is absent entirely. The term 'implied trust' is often used to describe trusts which have no written instructions, or deed, as compared to incomplete or ambiguous deeds as in the category of 'resultant trusts'.

The term 'resultant trust' is not totally universal and often the two terms are used interchangeably. In the case of Re: Vandervells Trusts ${ }^{69}$ Megarry J. used the terms conjunctively in drawing ' . . . the distinction between the two classes of resulting or implied trust, describing the first as 'automatic resulting trusts' and the second as 'presumed resulting trusts'. ${ }^{70}$ In this verdict the terms resulting and implied were used to mean the same concept, the distinction was drawn between two types of implied trust.

To refer to a resulting trust as opposed or distinct to an implied trust is not strictly correct as a resulting trust is an implied trust. Where applicable, resulting trusts are a sub-category of implied trusts not a category set apart.

The essential element is that implied trusts occur in the event that a deed or written instrument fails to cover all trust property, is vague, or totally absent and the conduct of the parties is such that they show clear intent that a trust is desired to exist.

The implied trust can come into existence in the case where a testator ' . . bequeaths all his property to trustees upon trust for various persons and purposes but does not

\footnotetext{
${ }^{69}$ Meagher and Gummow, above n 9, 285.

70 Ibid.
} 
dispose of the whole beneficial interest in the property. In such a case the trustees will be trustees for the testator's next-of-kin of the part that is not disposed of. The trust arises in this case from the fact that if a person disposes only of a portion of his beneficial interest in his property the law will presume that what has not been disposed of is still his own and will hold the legal owner a trustee to that extent for the benefit of the settlor., 71

'An implied trust then would mean that, although the trust was not directly expressed, it was to be inferred from the words or conduct of the parties. ${ }^{, 72}$

In Lord Mansfield's ${ }^{73}$ terms ". . . nothing in Law is so apt to mislead as a metaphor", and the term 'resultant trust' which applies to the situation where not all property is covered and the trust that 'results' as to the remainder, is such a metaphor.

Implied trusts therefore, may arise from a number of situations:-

A. Non-disposal of beneficial interest (resulting trusts). -

(i) No Trusts Stated - the total absence of a trust deed;

(ii) Trusts Declared as to part of property - a surplus of property remains unspecified in the deed;

(iii) Failure of Express Trust - the beneficiaries predeceases the testator, uncertainty or illegality of purpose or another technical, legal failure;

(iv) Failure of purpose of loan - funds loaned for a specific purpose which cannot be applied to that purpose for other reasons, the funds become trust property on behalf of the lender with the borrower as trustee;

(v) Un-exhausted residue - similar to (iv) in that an excess of funds may provided for a specific purpose ie the payment of debts, a trust results to the excess; and

(vi) The failure of engrafted trusts - involves trusts created by will, the property becomes that of persons other than the residuary beneficiaries or next-of-kin. An example is that of an express trust which bequeaths certain property to a person on certain terms and conditions which subsequently fail. The property then, unintentionally, passes to another party that the testator did not intend it to pass.

\footnotetext{
71 Ibid, 64.

72 Ibid, 65.

${ }^{73}$ Mansfield, William Murray, Earl of , Lord Chief Justice of England, 1756-93.
} 


\title{
B. Purchases in Another's Name.-
}

Simply put, wherever the case wherein the transfer of property takes place to a party, other than the party proven to be the person who has provided the funds for the purchase, a residual trust is presumed. With certain exceptions among relatives by blood or marriage, the resulting trust stands in favour of the person providing the funds for purchase with the registered proprietor as trustee. The authority is Dyer $v$ Dyer $^{74}$ and it has been confirmed that this represents the law today in Australia in the case of Napier $v$ Public Trustee (WA), where his Honour said:

\begin{abstract}
The law with respect to resulting trusts is not in doubt. Where property is transferred by one person into the name of another without consideration, and where a purchaser pays the vendor and directs him to transfer the property into the name of another person without consideration passing from that person, there is a presumption that the transferee holds the property upon trust for the transferor or the purchaser as the case may be. This proposition is subject to the exception that in the case of transfers to a wife child (including someone with respect to whom the transferor stands in loco parentis) there is a presumption of advancement so that the beneficial as well as the legal interest will pass. Each of the presumptions may be rebutted by evidence. ${ }^{75}$
\end{abstract}

There is a plethora of cases relating to the purchase of property in another's name and the presumption of advancement, chiefly centred on the relationship between the parties and the rebuttal of the presumption. It appears strongly that unless the rebuttal is clearly evidenced that the person holds the property as nominee for the purchaser, the presumption will hold. ${ }^{76}$ However the bounds of the relationship are very restrictive, the parties must be legal spouses and/or their children, by birth or loco parentis. The presumption does not extend to siblings, ${ }^{77}$ issue of siblings, ${ }^{78}$ spouses of issue, ${ }^{79}$ or issue of issue,${ }^{80}$ nor does it extend to common law spouses. ${ }^{81}$

It is important to be aware that rebuttal is not difficult and evidence may be given either in writing or verbally and by the acts of the parties, that the presumption was not meant to take place. A parent may have simply advanced a loan to a child and had no intention of granting a permanent gift.

Such may be the case where a parent might loan a married child the deposit for the purchase of a home. The loan may never be meant as a gift for the reasons of fairness to other children or moral or personal reasons, in such case the intent should be stated

\footnotetext{
74 (1788) 2 Cox 92 at 93; 30ER 42 at 43.

75 (1980) 32 ALR 153 at 158.

${ }^{76}$ Heard v Pilley(1869) LR 4 Ch App 548.

77 Novak v Novak [1959] VR 137 at 140.

78 Russell v Scott (1936) 55 CLR 440.

79 Knight v Biss [1954] NZLR 55.

${ }^{80}$ Soar v Foster (1858) 4 K \& J 152 at 157; 70ER 64 at 66.

${ }^{81}$ Calverley v Green (1985) 155 CLR 242.
} 
either verbally or by way of a letter to the child. Events as outlined are a common occurrence as every parent may well be aware.

There has been a bias in English courts that the presumption of advancement was certain on behalf of a husband to a wife but not so of a wife to a husband. That bias stems from the medieval concept that wives were nearly as valuable as cattle, generally in modern Australian courts that bias will not stand, certainly under the wide powers of the Family Court under the Family Law Act 1975 (Cth). The treatment is outside the scope of this paper and ignored as irrelevant and merely a matter of interest in the treatment of the law of trusts in Australia in the twenty first century.

\section{Constructive Trusts}

Constructive trusts differ from resulting or express trusts in that they arise not from intention (expressed or otherwise), by a party to construct a trust, but rather from operation of the law. The law does not consider intention as an element of determining the existence of the trust; in fact the constructive trust may arise from a breach of the law such as fraud, conversion, theft or misappropriation of money, wether by intention or not.

It is possible that reinstatement or restitution or stolen property or money does not end the matter as the thief may benefit from the earnings or income to the property whilst it in his charge. 'Thus, in Black $v$ Freedman ${ }^{82} \mathrm{O}$ 'Connor J held that 'where money has been stolen it is trust money in the hands of the thief and he cannot divest it of that character. $^{, 83}$

The lack of intention may not arise from a criminal act, but from any act by which one party acquires a benefit through the use of the property of another. In the absence of permission or instruction by the owner implied or expressed, a constructive trust arises. Directors of companies, employees, estate agents, solicitors, ships officers, trustees acting outside their express authority, are situations where constructive trusts may arise if they obtain or accrue a benefit.

Dishonesty is not an element, the persons may have acted in an honest but mistaken belief or as agents of emergency, and nonetheless they become trustees of a constructive trust.

Thus, in Brown v Litton, ${ }^{84}$ where the mate of a ship took possession of the deceased captain's money and effects during the course of a voyage and traded with the money, he was held to be a constructive trustee of the profit made. The captain had expressed no intention, directly or indirectly, of entrusting his money to the mate, but the court held that the latter could not hold the profit made for his own benefit. There was thus no question of intention, express or implied, to create a trust, but the court simply imposed a trust in order that justice might be done. This principle applies

\footnotetext{
82 (1910) 12 CLR 105.

${ }^{83}$ Meagher and Gummow, above n 9, 312.

${ }^{84}$ (1711) 1 P Wms 140, ER 329.
} 
wherever an express trustee makes a profit by reason of his office. ${ }^{85}$ It applies also where strangers to the trust have acted as trustees, or have participated in the fraud of a trustee or improperly received trust property knowing that it is trust property. ${ }^{86}$

As long as human nature prevails on the planet the constructive trust will remain with us, though its existence is do more to the idea of justice rather than to the vagrancies of taxation professionals and legislators.

\section{Trust accounting}

'There is no statutory form or requirements in respect of the trust accounts, although the deed may specify how they must be kept. The accounts should be kept in a form that is appropriate to the business or activities of the trust. ${ }^{, 87}$

Unless the trustee is a reporting corporation under the provisions of the Corporations Law ([State Act]) 1990, or the trust deed requires such, there is no requirement as to audit reporting or financial accounts produced. It is usual and recommended however that the following statements be produced and accounts kept in an auditable fashion.

Trading, Profit and Loss and Balance Sheets;

Statement of cash flows and notes to accounts;

Record of beneficiaries accounts;

Record of income and capital accounts and schedule of beneficiaries entitlements;

Record of Trustees exercise of discretionary decisions where applicable;

Trustee's statement as to ongoing validity of the trust as to breaches of the trust insolvency and the like. Similar to a directors statement and report to shareholders; and

A compilation report by an accountant as to "unaudited financial statements".

A minute book and schedules of assets should also be kept. In the case of incorporated trustees subject to audit under the provisions of Corporations Law or requirements contained within the trust deed the accounts, methods of keeping and final statements required will be contained within the appropriate deed or legislation. In such cases the accounts will be kept in accordance with accounting standards and audited accordingly. The auditor will also be required 'to verify that:

\footnotetext{
${ }^{85}$ Keech v Snadford (1726) 2 Eq Cas Abr 741; 25 ER 223.

${ }^{86}$ Re Fyre-Williams[1923] 2 Ch 533; Meagher and Gummow, above n 9, 65.

${ }^{87}$ Hodgson, above n 4, 66.
} 
(i) the trustee has not exceeded his powers;

(ii) there has been no breach of trust;

(iii) the accounting records are correct; and

(vi) income and capital transactions have been identified and accounted for correctly in far as this may affect the rights of the beneficiaries, 88

Generally the reporting and record-keeping requirements of the trustee will be largely influence by Corporations Law and the penalties for falsification, fraud or neglect will be in accordance with that legislation, as well as the common law remedies available to the beneficiaries for breaches of duty.

It is important to note that trustees of corporations and the days of the individual trustee are waning. The chief reasoning is that of limitation of liability afforded by Corporations Law to incorporated bodies. The common commercial structure in modern times is most likely to be - Bloggs Pty Ltd, as trustee for the Bloggs Family Trust, trading as Bloggs Furniture, with Joe and Mary Bloggs as directors of a fully paid \$2 company that has no other activity other than trustee. Joe and Mary and their three adult children are the beneficiaries. Joe and Mary distribute the funds to all five but the children never receive a cent. In modern times the more educated children threaten their parents with exposure to the Australian Taxation Office.

In practical terms it is far more suitable to simply trade in the company structure. As company tax rates fall, the attractiveness of the complex and dangerous trust structures to minimise taxation burdens is losing its appeal.

88 Ibid, 67. 


\section{PART B. Taxation Law issues relating to Trusts}

\section{Taxation of Trust Distribution under Australian Income Taxation}

\section{Law}

"Sir, we go Waltzing Matilda with you."

(Sir John Grey Gorton 1968 in support of US President Nixon on the Vietnam War; Prime Minister of Australia 1968 -1971, 1911 - )

Though much change is proposed to amend the manner in which trust income is to be treated in Australia, the position outlined is current at the time this paper is being prepared. It is the only position that can be held as future proposals are many and the ultimate outcomes uncertain. Future proposals and possible outcomes are addressed later under the headings Future Legislation (12.) and Suggested Outcomes (13.).

The operative provisions of the Income Tax Assessment Act $1936{ }^{89}$ are contained in Division 6 comprising sec 95 to 102. 'The object of Div 6 is to "secure payment of tax upon the whole of the net income of a trust estate, either from a beneficiary or the trustee, whether or not the income is paid over to or on account of the beneficiary': per Latham CJ in Tindal v FC of $T^{90}$.,91

'Many of the income and deduction provisions of the ITAA 1997 and ITAA $1936 \ldots$ contain special provisions modifying or dealing with their applicability to income flowing through trust structures or dealings with trust structures. 92

'The Government has announced that, from 1 July 2001, it intends to tax certain trusts as if they were companies, under a redesigned company taxation system called "entity taxation". This will significantly affect the way in which such trusts are taxed.'93 This proposal will be further dealt with under the heading Future Legislation, however, at the time of writing, the Government has deferred the introduction of changes for at least one year until 2002.

Generally the taxation of trust income is in the hands of the beneficiary and is assessed in accordance with ordinary concepts. Every trustee is liable to lodge a tax return however the trust is usually not assessed as the entity deriving the income. 'Tax is either imposed on the trustee or the beneficiary in respect of elements of that

\footnotetext{
${ }^{89}$ At this point due to transitional effects of the introduction of tax law improvements and political changes from the Keating Labor Government to the Howard Coalition Government, Australian Tax Law is covered partially by the previous Income Tax Assessment Act 1936 (Cth) and the Income Tax Assessment Act 1997 (Cth), therefore reference must be made to both Acts when applying tax law.

90 (1946) 72 CLR 608 at p 618; 8ATD 152 at p 155.

91 Robin Woellner et al, 1997 Australian Taxation Law $7^{\text {th }}$ ed. (1997), 1018 - 19.

92 Deutsch et al., above n 8, 1097.

93 Ibid.
} 
taxable income as determined by Div 6, rather than on the overall taxable entity as an entirety. ${ }^{94}$

The general principle is to tax the beneficiary wherever possible on the income distributed and that income retains is character as it had into the hands of the trustee. Certain provisions apply as to the distribution to minors or in the cases where the beneficiary is not resident or undisclosed.

In such cases tax rates are set much higher than for individual resident rates and after a small tax free threshold, $\$ 416$ in the case of resident minors, are usually the highest marginal rate of $47 \%$. In the event that no beneficiary is presently entitled the trustee is assessed at $47 \%$ under $\mathrm{S} 99 \mathrm{~A}$ of the entire amount plus medicare levy. Interestingly the medicare levy is imposed even though no individual is specifically covered or identified. Medicare levy is not imposed on other entities such as companies.

Clearly the Government intends to collect the maximum revenue in the event that persons wish to conduct themselves anonymously, as they would in a 'Blind Trust'. There is an underlying intention to inhibit the existence of undisclosed income. The rate set ' ... where the trustee fails to disclose to the Commissioner within the specified period the ultimate beneficiary or beneficiaries in respect of that share of net income. . . ${ }^{95}$ is $48.5 \%$, which represents the highest marginal rate of $47 \%$ plus $1.5 \%$ medicare levy.

If the taxation and legal system cannot force trust structures that are intended to minimise or avoid tax, or any other reason that beneficiaries and trustees may want to disguise income or assets, then the Government, on the assumption that the structure is dishonest, will simply tax them out of existence. If they want to hide their assets and income so badly they can jolly well pay, and pay handsomely.

It should be noted that Edward I had a similar plan for 'bringing the Scots to heal'. "If we can't starve them out; we'll breed them out." ${ }^{96}$ It would be truly unfortunate if the Howard Liberal Government were to face the same fortunes at the hands of the middle class Australia which until now have been the very nub of support of the Liberal Party.

\footnotetext{
94 Ibid.

95 Ibid, 2075.

96 Allegedly attributed to Edward I (Longshanks) on introducing the law of Ius Prima Noctis by which the Lords took a bride on her wedding night to exercise their power over the peasants. Anecdotally the incident led to Sir William Wallace killing the Sheriff of Lanark and finally led to the Scottish Revolt at Bannockburn led by Robert the Bruce.
} 


\section{Capital Gains Tax implications}

\section{"By 1990 no Australian child will be living in poverty."}

(Robert James Lee Hawke (1983) Prime Minister of Australia 1983 - 1991, 1929 - )

An attempt at a detailed and accurate treatment of this topic is as optimistic as $\mathrm{Mr}$ Hawke when he became Prime Minister of Australia and Alan Bond won the America's Cup.

There is nothing as uncertain as a 'certainty', as any bookmaker will testify. The application of Capital Gains Tax to trusts and trust distributions is a fine example of what a committee can achieve when it really tries to reach simple answers.

The distinction between income according to ordinary concepts and capital gain becomes difficult to establish from the moment the trust is created. As with partnerships, trust income often retains its character ${ }^{97}$. 'Income in the hands of a presently entitled beneficiary retains the same character as that income had in the hands of the trustee. Hence, any part of the net income of the trust estate that represented a capital gain to the trust will retain its character as a capital gain as part of the presently entitled beneficiary's share in that net income. The beneficiary will have the ability to offset the capital gain against capital losses. ${ }^{, 98}$

The offset of capital losses is not clear. In the case of a partnership the offset is simply applied to capital gains in the hands of the partner or in the case of a trust offset against losses within the partnership. The offset is not as clear in the event where a beneficiary has capital gains other than those within the trust. 'Losses incurred by a trust, unlike losses incurred by a partnership, remain trapped in the trust and are not distributed to beneficiaries. The beneficiary is unable to utilise any portion of a loss in a trust as an offset against any tax liability in respect of income that may be derived from sources other than the trust. ${ }^{, 99}$

A beneficiary who has capital assets and disposals separate to the trust is therefore at a disadvantage. If a capital gain is incurred by that taxpayer on the one hand and a capital loss incurred by the trust to which that taxpayer is beneficiary, then any capital gain is assessed and no offset takes place. The trust loss is prevented from being applied to the capital gain despite the fact that the beneficiary's interest in the trust has diminished.

Generously the beneficiary can apply other CGT losses to trust capital gain but cannot take advantage of indexation if before 21 September 1999 or the CGT discount if after. The CGT discount of paying tax at the normal rate of tax on $50 \%$ of the capital

\footnotetext{
${ }^{97}$ Baker v Archer-Shee [1927] AC 844.

98 Deutsch et al., above n 8,1101.

99 Ibid, 1102.
} 
gain '.. is not allowed for a trustee assessed under s 98(3) or s 99A of the ITAA $1936 .{ }^{100}$ The taxpayer loses both ways, tax is liable and the overall wealth is reduced.

The treatment of capital gains on trust assets is straight forward "where an assessable capital gain is realised it will form part of the net income of the trust under s 95 of the ITAA 1936. As part of the net income of the trust the capital gain can be allocated by the trustee to a beneficiary so that the beneficiary becomes presently entitled to that capital gain for trust law purposes. ${ }^{101}$

Given the assumption that the beneficiary is the recipient of a trust established for reasons other than tax planning, the prevention of the use of trust capital losses to other capital gains, may be accepted as the other benefits outweigh that disadvantage. However simplicity ends at this point. At the establishment of the trust a Capital Gains Tax event occurs. 'Section 104-60(1) provides that:

CGT event E2 happens if you transfer a CGT asset to an existing trust., 102

The High Court has supported that view that a transfer has taken place ${ }^{103}$ albeit in a legal sense which may not be entirely equitable. Some respite to CGT is afforded in that if the asset was acquired by the transferor prior to 20 September 1985, Section $104-60(6){ }^{104}$ provisions allow any capital gain or loss to be disregarded.

The mere establishment of a trust therefore creates a CGT event and all the implications and consequences relating thereto. Curiously Section 104-60(4) provides that the transfer at establishment is the market value when the asset is transferred. It appears that the assumption is that the transferor will always attempt to transfer at less than market value or gift the asset. The assumption does not allow for the circumstance of purchase at an arms length whereby the trustee is astute or fortunate enough to purchase assets at less than market value.

A CGT event, CGT event E5, also takes place when the trust asset is finally vested in the beneficiary.

The overall view as to capital gains tax as it applies to trusts is that capital gains events occur:-

(i) at the establishment of the trust;

(ii) during the life of the trust, though losses cannot flow through to the beneficiary, and certain gains assessable to the beneficiary though the actual income is not received by the beneficiary. A beneficiary may

\footnotetext{
100 Ibid, 253.

101 Graeme S Cooper and Lachlan R Wolfers, Cooper's TLIP Capital Gains Tax (1999) 14009.

102 Ibid, 14013.

103 Corin v Patton (1990) 169 CLR.

104 ITAA (1997).
} 
only be entitled to the income of a trust and not to the results of capital proceeds in accordance with the terms of the trust deed, but subject to CGT according to Div 6.; and

(iii) at the termination of the trust:

In additional the interest in the trust may include a capital interest in which case the disposal by the beneficiary of that interest in a trust, in the case of a unit trust a $\boldsymbol{C G T}$ event E8 occurs.

The calculation of capital gains or losses is in accordance with the provisions of the CGT legislation contained within ITAA 1997, and is outside the scope of this paper.

The above discussion is provided to raise awareness of the CGT implications on beneficiaries and trustees of trust. Generally the point is made that the basis of the existence of trust which is the principal of equity is disregarded when considering the CGT implications of taxation as it relates to trust distributions. This is the direction that legislation is heading which will see the ultimate demise of trusts in the modern era if legislators pursue the legal approach over equity. 


\title{
9. $\underline{\text { Non-Resident Trusts }}$
}

\author{
"Life wasn't meant to be easy"
}

(John Malcolm Fraser 1982 Prime Minister of Australia 1975 - 1983, 1930 - ,)

Under the provisions of British Common Law of Trusts, an express trust can be established under many variations. The terms and conditions of the deed are limited only by the imagination and desires of the person creating the trust. The only restriction being that the object or purpose is permitted by law. Creators of trusts whose primary motive is to avoid taxation or to cheat creditors would never admit that motive. To prove otherwise may be obvious but impossible as the real intention can be cloaked in a myriad of otherwise bona fide reasons.

Provided the terms of the trust comply with the certainties of intention, subject matter and object ${ }^{105}$ settlors can direct the trustee to an innumerable variety of duties and powers. Given that all the essential elements exist a valid trust can thus be created with focus and variations in an accordingly innumerable variety.

In the South Pacific nation of Vanuatu and other similar tax haven jurisdictions, accountants and lawyers have taken advantage of that flexibility of trust construction. The existence of that type of trust is neither condoned nor encouraged by the government of Vanuatu.

The Cook Islands government has on the other hand provided legislation to recognise such structures provided they do not trade or deal in the Cook Islands with Cook Islanders. The Vanuatu government has in fact attempted to limit the exploitation of the legal framework by introducing the Mutual Assistance in Criminal Matters Act (1990) and the Serious Offences (Confiscation of Proceeds) Act (1990). ${ }^{106}$

Unfortunately such legislation is relatively ineffectual in preventing money laundering as the offenders have to be apprehended and successfully prosecuted for the laws to take effect. As there exists little framework for the detection and prosecution of such activities the legislation is little more than 'window dressing' to world governments.

The '. . . professional infrastructure of accountants, banks lawyers and trust companies . .. 107 take advantage of the lack of parliamentary and legal sophistication of the native Pacific Islanders as they struggle to build sustainable economies in the wake of independence from their colonial masters. In many cases the old colonial masters simply vacated their former colonies without leaving any formal government structure or trained administrators. The natives found themselves serfs and villeins of the colonial era one day and leaders of nations in the twentieth century the next.

\footnotetext{
${ }^{105}$ Meagher and Gummow, above n 9, ch5.

106 A Financial Centre Synopsis of the Republic of Vanuatu BDO International B.V. Chartered Accountants \& Business Advisers, Linin Highway, Port Villa Vanuatu Jan 2001, 6.

107 Ibid.
} 
It is in this naive legal and political environment that the 'tax haven' industry proliferates. In the jurisdiction of Vanuatu, only two tax collection systems exist, a $12.5 \%$ VAT and a $70 \%$ import duty.

The VAT system is clearly targeted at tourism and in Vanuatu that intention is clearly pronounced. A single economy, with a single income and a single tax system has resulted in the predicted escalation in the differences between rich and poor.

An observation of the large number of Australians entering the country as residents implies that many are taking advantage of the single tax system. Clear signs of wealth are present and demonstrated by the impressive villas located on spectacular vantage points around the surrounding mountains. Without the burden of other taxes expatriates can keep local consumption to a minimum and enjoy otherwise unattainable lifestyles.

The burden of taxation is borne solely by the tourists and local inhabitants.

As the increased costs discourage tourism, the residents will be burdened by the inequitable tax, driving them further into poverty while the expatriates continue to frolic free of the burdens they have had to shoulder in other taxation jurisdictions. In the writer's previous paper International Aspects of the Australian Goods and Services Tax (GST), ${ }^{108}$ the ultimate outcome of a GST regime was predicted and Vanuatu is proof of that outcome.

General appearances of poverty are throughout the country. Roadways and public buildings are in disrepair and reveal signs of neglect, officials are blasé and have little interest in carrying out their duties and the native population have resorted to living in shacks clinging to the hillside. Public servants have not been paid for many months and public utilities are at rudimentary levels. The cost of living has soared beyond the scope the majority of inhabitants.

The Vanuatuan economy demonstrates that the GST/VAT taxation system fails the effectiveness test, in that it simply fails to fund sufficient government revenue to provide essential services by western standards.

It is in this economic, legislative and political climate that taxation avoidance industries thrive and the trust structure is the taxation vehicle used to carry out the purpose.

The accounting and legal professions openly boast of the lack of a comprehensive taxation system through publications on the Internet. ${ }^{109}$

On Independence Day (30th July 1980), the colony of New Hebrides became the Republic of Vanuatu. There was no real transition from the colonial powers of Britain and France. They simply departed in similar fashion to their arrival, sudden

\footnotetext{
108 Alexander R Fullarton, International Aspects of the Australian Goods and Services Tax (GST) (paper PGrad Dip, Curtin University, 2000).

109 For example see The chartered accountants KPMG website available at $<$ http://www.kpmg.com.au>.
} 
and unheralded. The confusion did not provide for an administration and modern bureaucracy to administer the new country.

In order to fill the legal void Vanuatu's Constitution states ' . . . that, until otherwise provided by Parliament, pre-independence British and French laws shall continue to the extent that they are not expressly revoked or are incompatible with the independent status of the Republic. ${ }^{110}$

The important ramification of the adoption of the laws of the colonial masters is that as an ex-British colony, the law of trusts was adopted. Had the colony been exclusively French the trust structure would not exist to be exploited. However history has now set the course of the legal framework of Vanuatu and that framework is the central point around which the 'tax haven' system works.

A trust system has been constructed by which assets can be effectively and totally screened from all parties including the beneficiaries. Through the creation of a 'blind trust $^{111}$ the distribution to, and the identity of the beneficiaries is completely secret. In little more than legal fraud, the 'blind trust' operates by virtue of and in the following manner.

The 'blind trust' is correctly identified as a discretionary trust with undisclosed beneficiaries. The type of trust could exist in Australia however the tax avoidance benefit to the beneficiary is caught under s 99A of the Income Tax Assessment Act 1936 whereby the trustee is liable for the tax at $47 \%$ of the entire amount of net income of the trust.

By moving the trust offshore to Vanuatu the Non-resident trust is subject to Vanuatuan income tax. The Australian income is subject to assessment pursuant to $\mathrm{s}$ 99 at the relevant rates ${ }^{112}$ but any other income is simply not assessed, this could be share dividends, interest, rents and other non-personal exertion income.

As no taxes other than VAT and Import Duty exist in Vanuatu, professionals are free to exploit the law of trusts to an unimagined extent. The combination of British Law and the absence of any form of income or wealth taxes allow the avoidance of income tax and the secreting of wealth such that the '. . . finance centre activities . . . representing less than $0.2 \%$ of Vanuatu's population, are responsible for over $12 \%$ of Vanuatu's Gross Domestic Product.'113

Australian legislation provides for the trust structure of the 'blind trust'. 'Where no beneficiary is presently entitled to the whole or part of the income of a trust estate, the trustee will be assessed and liable to pay tax on that portion of the net income.' 114

\footnotetext{
${ }^{110}$ A Financial Centre Synopsis of the Republic of Vanuatu, above n 92, 5.

111 Deutsch et al., above n 8, 1368.

112 Ibid, 2073.

113 Lindsay Barrett, Chartered Accountant, Article - Money Matters Island Spirit; Air Vanuatu Inflight magazine Pacificads Port Villa, (Vanuatu Issue 13 2001) 13.

${ }^{114}$ Deutsch et al., above n 8, 1117.
} 
'The Section under which the trustee will be assessed will be either s 99A of s 99 . These sections are interrelated and must be read together to determine which will apply. However, only (one) will apply in any given situation.' 115 'Blind trusts' can and do exist in Australia.

The Western Australian Transfer of Land Act as amended 1987 prevents the disclosure of trusts in that 'The Registrar shall not enter in the register book notice of any trusts unless they are set out in the body of the original Crown grant'. ${ }^{116}$ As to the ownership of real property in Western Australia therefore the beneficial owner is not to be disclosed. The trust may declared in a separate document, ${ }^{117}$ but the trust is compelled by law to be undisclosed.

In Vanuatu, and other similar 'tax haven' jurisdictions, that permit the exploitation of the trust as a tax avoidance vehicle, the operation of the 'blind trust' is surprisingly simple. The avoider (settlor) divests all of his(her) wealth and income to the trust. Under the terms of the deed he(she) and at least one other are made beneficiaries of the trust.

As the trust distribution is at the discretion of the trustee, and the beneficiaries are undisclosed, the settlor can quite legally declare to be destitute and with out financial support. Should the beneficiary desire funds or goods for any reason he(she) requests the trustee through an attorney to distributed funds to whatever purchase the beneficiary desires.

The ownership of the good or chattel continues to be the property of the trust. The beneficiary, undisclosed, simply uses the property for his own benefit but without legal ownership. For example Alan Bond may be able to drive a new Mercedes without fear of creditors confiscating it for unpaid debts.

Australian income will be taxed at non-resident trust rates under s 99A which is the highest marginal rate of $47 \%$ of all net income. The 'tax haven' advantage is therefore reduced by the provision of s 99A, at least to the Australian income but the ability to avoid creditors, family courts or the Australian Taxation Office, continues to attract individuals to the offshore, non-resident trust.

As discussed later under the heading of Future Legislation, proposed trust legislation will be unable to deal with these types of trust, at least as to wealth alienation.

\footnotetext{
${ }^{115}$ Ibid.

${ }^{116}$ Transfer of Land Act 1873-1972 (WA).

117 Ibid.
} 


\section{Stamp Duty and Land Tax issues}

"Once you slow the growth under 3 per cent, unemployment starts to rise again. Then you're gone. You're a banana republic"

(Paul John Keating 1993 Prime Minister of Australia 1991 - 1996, 1944 - , )

Taxes which are incurred by the operation of a trust in addition to the impost of Commonwealth Income and Capital Gains Tax provisions are State Stamp Duties and Land Taxes, where applicable. Local Government rates also apply to land held by trusts and are levied by each Local Authority according to their respective charters.

As the taxes and duties are the jurisdiction of each State the application and costs will vary accordingly.

The rates of duty vary from State to State according to the various Stamp Acts:-

$\begin{array}{ll}\text { New South Wales } & \text { Duties Act } 1997 \text { (NSW) } \\ \text { Victoria } & \text { Stamps Act } 1958 \text { (Vic) } \\ \text { Queensland } & \text { Stamp Act } 1894 \text { (Q1d) } \\ \text { South Australia } & \text { Stamp Duties Act } 1923 \text { (SA) } \\ \text { Western Australia } & \text { Stamp Act } 1921 \text { (WA) } \\ \text { Tasmania } & \text { Stamp Duties Act 1931 (Tas) } \\ \text { Australian Capital Territory } & \text { Duties Act } 1999 \\ \text { Northern Territory } & \text { Stamp Duty Act } 1978 \text { (NT) }\end{array}$

Due to the anticipated removal and review of State and Territory indirect taxes to be carried out in accordance with Australia's New Tax System which came into effect on 1 July 2000, detailed analysis of these tax implications on trusts is superfluous.

It is sufficient to be aware that until the review prior to $2005,{ }^{118}$ trust documents, deeds, land transfers and dealings attract Stamp Duty. 'In all jurisdictions, with the exception of the ACT, unstamped instruments liable to duty in the relevant jurisdiction are neither admissible as evidence in the courts of nor enforceable in that jurisdiction'. ${ }^{119}$ It is also noted that one of the pivotal issues affecting the outcome of

\footnotetext{
118 Intergovernmental Agreement on the Reform of Commonwealth - State Financial Relations (IGA) June 1999, <http://www.taxreform.ato.gov.au > at May 2001.

119 Deutsch et al., above n 8, 1936.
} 
the Halloran case cited in chapter two ${ }^{120}$ was the failure to pay stamp duty on the land transfer instruments so vital to the case.

The review is intended to remove the Stamp duties levied on: non-residential conveyances; non-quotable marketable securities; leases; mortgages, bonds, debentures, and other loan securities; credit, instalment purchase and rental agreements; and cheques, bills of exchange and promissory notes. ${ }^{121}$

Until that time trusts, and all other parties, are effectively being subject to dual taxation on both the Federal level (Goods and Services Tax) and the State Level (Stamp Duties) at the same point of transaction. The duality of taxation is not illegal in a Constitutional sense, in fact 'in 1978, Commonwealth legislation was enacted which allowed the States to levy an additional State income tax surcharge or provide a rebate. However, the high marginal tax rates already prevailing at the time meant that no State acted upon this legislation and the legislation was eventually repealed in 1989'. ${ }^{122}$

In practice it places a heavier than intended and quite disguised, burden of taxation on taxpayers which varies from State to State. Presently the discrepancy of fuel prices between States is an example of the results of double taxation. As will be stated later, once the powers to tax have been handed over by States to the Commonwealth they will never be returned to the States. The outcome of the promised review will be awaited with interest by all parties, chiefly taxpayers.

Transactions which may attract stamp duty subject to jurisdiction and relevant treatment of assessability or exemption include -

Initial transfer of legal ownership to the Trustee, in New South Wales it will be subject to stamp duty; in Victoria an exemption is available if there is no change in beneficial interest; in Western Australia the Commissioner has the discretion to determine whether or not the transfer is in fact a transaction;

Changes of trustee, usually attracts stamp duty at a nominal rate subject to a minimum in New South Wales and Victoria which is far higher than any other jurisdiction;

The registration and variations of the trust deed, varies from State to State;

Registrations and dealings with instruments of land, title and mortgage registrations, varies from State to State;

\footnotetext{
${ }^{120}$ Halloran v Minister Administering National Parks \& Wildlife Act 1974 [2006] HCA 3.

121 Ibid.

122 Tax Reform and the GST: An International Perspective. Binh Tran Nam ed. (ATAX Seminar Papers, 1998) ch 3, 40.
} 
Land Tax on Land held by the trust if any, varies considerably in methods of setting tax base and rate from State to State;

Transfer of Shares, varies from State to State; 


\section{Personal exertion trusts and interposed entities.}

"Those who have long enjoyed such privileges as we enjoy forget in time that men have died to win them."

(Franklin Delano Roosevelt President of the United States of America 1933 - 1945, 1882 - 1945)

It is the writer's opinion that Western Australian law is either unknown or unacknowledged in the major Eastern States of New South Wales and Victoria. As our forefathers feared at Federation, the eastern States would ignore Western Australia's interests once the Commonwealth came into existence. The concept of State's rights and the general shift of power from the States to the Commonwealth are examined under the heading of 'Suggested Outcomes'.

In examining 'interposed entities' the concept of 'separate legal entities' must be addressed. Curiously whilst it is legally accepted that individuals and companies are separate legal entities under Australian Tax Law, partnerships are not recognised as such under the provisions of current taxation legislation. A group of individuals bound under the provisions of the Partnership Act $1895(W A)^{123}$ is ignored as a separate legal entity by Federal Taxation Legislation. The lodgement of the form ' $\mathrm{P}$ ' for partnerships is a 'courtesy document' which is used merely for bookkeeping and reconciliation purposes.

The assessments relating thereto is not based upon the partnership but rather in the income is assessed in the hands of the individual. The concept of 'partnership tax' does not exist. The deed of a partnership agreement does not have standing under the current tax regime other than as evidence of the income distribution. ${ }^{124}$ Despite being a legal document which is enforceable by the Court as to the rights and duties between partners and partners and third parties the partnership agreement never attains the recognition of a 'Trust Deed', in a taxation law sense.

There are other key differences between partnerships and trust in the way they are treated for tax purposes:-

(a) All income, less allowable deductions, is taxed in the hands of the partners whether it is actually distributed or not. Only that income distributed to the beneficiaries is taxed in the hands of the beneficiary;

(b) Partners are assumed to have equal control and participation in the business of the Partnership and can be actually examined as to their participation in the business. In the case where it is considered that the partner is not active the Commissioner of Taxation will consider that person not to be a partner; ${ }^{125}$

\footnotetext{
${ }^{123} \operatorname{Sec} 7$.

${ }^{124}$ Sec 91, Income Tax Assessment Act (1936) (Cth).

125 Australian Taxation Office Ruling TR 94/8.
} 
(c) Losses incurred in trade or capital disposals are allowed to 'flow through' to the partners. Beneficiaries do not benefit from the application of trust losses to other income in the way partners may apply partnership losses to other income;

(d) Partnership income retains its character, exempt income, capital gains, dividend distributions, primary production and the like are treated as such in the hands of the partners. ${ }^{126}$ Trust income also retains its character but losses cannot be distributed and applied against other income.

(e) Partners may loan monies to a partnership and vice-versa, the interest incurred is deductible and assessable in the hands of the parties as appropriate. Trusts are carried out for the benefit of beneficiaries and such loans would be treated as distributions to those beneficiaries.

The above comparisons with partnerships provide clarity when considering 'interposed entities' and 'personal exertion'. A partnership does not 'interpose' itself for tax purposes between the income of the enterprise and the treatment of that income in the hands of the individual tax payer.

The partner is entitled '. . . to take part the management of the partnership business. . .${ }^{127}$ the management of the trust is in the hands of the trustee. It is reasonable to assume therefore that the business and income distribution of a partnership is borne by and earned by involvement of the partners personally.

The use of a trust to take advantage of 'income splitting' requires and receives special attention by the Taxation authorities. The desire to split income is caused by Australia's progressive tax rate system and tax free thresholds. A trust is 'interposed' between the 'personal exertion' income of an individual and the distribution to beneficiaries, who take no part in the earning of such income in any way whatsoever,

Many examples of interposing trusts to split assessable income exist. Many professionals and trades people establish trusts to enable income splitting with family members to reduce taxation burdens. Cases of welders, plumbers, electricians, architects, accountants and the like have drawn the ire of legislators whereby it is blatantly obvious the family members take no active part whatsoever in the enterprise and that the trust is simply a taxation minimisation scheme.

The simply reality of the situation is that it is illogical to infer that an unskilled housewife, living in Perth, is actively involved in a highly skilled welding project in Karratha.

Should the taxpayer's attempt to form a partnership to carry out the same purpose it would fail for numerous reasons, licensing, regulatory or other legal or ethical requirements placed on the trade or profession such as the Law Society, the Medical

\footnotetext{
${ }^{126}$ Deutsch et al., above n 8, 1065.

127 Sec 34 Partnership Act 1895 (WA).
} 
Practitioners Board or such other professional or regulatory body which require partners to be qualified as such in order to be valid.

Numerous professionals such as Medical Practitioners, Dentists, Lawyers, Accountants and the like attempt to circumvent such controls which forbid splitting income with their spouses by way of partnership, by establishing trusts to achieve that end. Given the numbers of individuals and amounts of tax avoided it is little wonder the use of interposed entities to distribute the income earned by individual personal exertion, have become targeted by Tax administrators and legislators.

In the 2001 taxation year the earning of an individual solicitor for example is say $\$ 200$ 000, at least he wishes. The taxation assessed, ignoring rebates and other levies will be $\$ 81380$. By sharing that income with her husband, who cares for the home and children and has no other income the net tax on the same income is reduced to $\$ 68760$.

The limitations placed on infant beneficiaries under Div 6AA of the ITAA as to the tax impositions on income over $\$ 416$ effectively prevent advantages of income distribution to minor family members for the purpose of tax minimisation.

In a number of decided cases a taxpayer who formerly carried on business, either alone or in partnership, ceased to do so, and instead became employed by the trustee of a family trust, who had acquired the relevant interest of the taxpayer formerly carried on by the taxpayer, and who then employed the taxpayer to provide services similar to those previously performed directly by the taxpayer. By these arrangements personal exertion income of the taxpayer was treated as income of the family trust, available for division by the trustee among members of the taxpayer's family.

However, in Tupicoff $v$ FCT (1984) 15 ATR 1262 the Full Federal Court applied s 260 of ITAA 1936 to annihilate such arrangements, leaving the net profit of the trustee company to be assessed to the taxpayer. In addition, in FCT $v$ Gulland; Watson v FCT; Pincus v FCT (1985) 17 ATR 1 the High Court applied s 260 to invalidate these arrangements for tax purposes. ${ }^{128}$

Interposed entities and alienation of personal services income have both been exposed as mere contrivances for tax avoidance. The established principle of substance over form has foreshadowed yet one more nail in the coffin of the trust.

The following topic 'Future Legislation' will attempt to ascertain the direction that the Howard Liberal Government is likely to take but it is worth considering the following passage in the Australian Tax Handbook 2000, which will be the basis for future direction of interposed entity legislation.

The Ralph Review of Business Taxation, in its July 1999 Report, recommended (Recommendation 7.2) that payments received in respect of an individual who provides personal services through an interposed company, trust or partnership should be treated as income derived by the individual who provides the services where:

${ }^{128}$ Deutsch et al., above n 8, 755 . 
1. the interposed entity receives $80 \%$ or more of its income from one service requirer (or associate of that service requirer) during the year of income; or

2. the services are provided to the same requirer in the manner of an employee as determined by a range of specific criteria even if less than $80 \%$ of income is received from one service requirer (or associates).

An interposed entity will be able to obtain a decision or ruling from the ATO that the test in 1 does not apply.

The government announced on 15 November 1999 that it will introduce measurers to limit tax avoidance arising from the alienation of personal services income through an interposed entity as recommended by the Ralph Review: see Treasurer's Press Release No 74, in an ABC radio interview on 15 November 1999 that the proposed measures will only apply to incorporated subcontractors receiving $80 \%$ of their income from one person if they do not operate as a business. See also Treasury Fact Sheet 703 (available at www.treasury. gov.au). ${ }^{129}$

129 Ibid, 757. 


\section{Future Legislation.}

"Without inhibitions of any kind, I make it quite clear that Australia looks to America, free of any pangs as to our traditional links or kindred to the United Kingdom"

(John Curtin 1941 after demanding the return of Australian troops from the British to defend Australia; Prime Minister of Australia. 1941 - 1945, 1885 - 1945)

It is difficult if not impossible to suggest what is going to take place with the Howard Government's proposed legislation. In the time since this paper was first being prepared the Government has proposed and postponed or abandoned all of the proposals that were made at the time of the last Federal Election. It is hardly surprising that the Governments actions and statements are convoluted when it is realised that the Howard Government initially won the 1996 election on the basis that there was to be no Goods and Services Tax introduced.

The alleged 'mandate' to introduce the GST in the October 1998 election was entirely false. An urgent, scandalous rush transpired to introduce the GST legislation with the help of the Democrat Party in June 1999 as the Howard Liberal Government was about to loose its thin control of the Senate on July 1st 1999.

It is outside the scope of this paper to debate the morality and legality of such change of policy of the Howard Government but it is a fair example of how the Howard Government can and does change it policies after announcing the directions that it will follow.

For the purposes of this discussion, proposed legislation will be dealt with in line with the recommendations in the Review of Business Taxation of July 1999 prepared by an investigative committee chaired by John Ralph AO and known as 'The Ralph Report'. ${ }^{130}$

The Howard Government has placed great reliance on those recommendations and it is fair to assume that those recommendations will be the general direction of Australia's proposed taxation legislation.

Of significance is the key objective of chapter 22 of the report which states the objective of trust taxation legislation should be - 'To align the taxation of trusts as closely as possible with that of companies. However, issues specific to trusts will arise when incorporating them into a redesigned company tax system'. ${ }^{131}$

It is curious to note that an article in Taxation in Australia in May $1998,{ }^{132}$ the writer, a tax partner with Coopers \& Lybrand in Brisbane, Simon Gaylard, stated "We were warning people back in 1975 to be prepared for the possibility of trusts being taxed as

\footnotetext{
130 John T Ralph, Rick Allert and Robert Joss, Review of Business Taxation (July 1999) <http://www.rbt.treasury.gov.au/paper4> at 14th April 2001.

131 Ibid, ch 22.

132 Simon Gaylard Chartered Accountant Article - Trust Busters, (Taxation in Australia, Journal Taxation Institute of Australia, May 1998) 32, 516.
} 
companies and advising them to act cautiously". Either Mr Gaylard is an oracle of great note or did the 'Ralph Report' simply make a recommendation that was the direction that the Government wanted. Indeed if the Fraser Liberal Government of 1975 first muted the changes to tax trusts as companies and Australia has now had fifteen years of Liberal dominated government, why hasn't the change occurred?

The answer is that no matter how much the Australian Taxation Office and the successive Governments, Labor or Coalition, dislike trusts and suspect them as vehicles for tax minimisation and avoidance, which is true in a number of cases, they can't.

... the fact is that such trusts have been around for centuries, have well established uses and have attractive features makes them a political hot potato, especially since it is not only the wealthy that use them.

Despite the prevailing attitude, it's not easy for the Government to simply order all trusts to be taxed like companies. The reality is that the law allows trusts to operate as they are.

"It will take a brave Government to introduce a measure like charging company tax across the board to all trusts - especially discretionary trusts." 133

The deadline of July first 2001 to introduce the changes to the trust taxation system proposed by the Howard Government in line with the 'Ralph Report' to tax trusts as companies has now been postponed. It may well be postponed indefinitely.

One of the primary forces which influenced the government in deciding to introduce the Goods and Services Tax ('GST') laws was pressure from the Organisation for Economic Co-Operation and Development ('OECD'). All Member nations, other than the United States of America ('US'), had a GST/VAT system and in the interest of greater taxation uniformity, pressurised Australia to comply with their system.

OECD influence cannot be overlooked and in attempting to introduce legislation to combat the misuse of trusts as tax planning/avoidance vehicles. The area concerned with the introduction of legislation is the OECD position on harmful tax competition.

The OECD recognises that 'it is increasingly difficult for individual countries to combat effectively the spread of harmful tax practices without the risk of putting their taxpayers and economies at a competitive disadvantage. There is, therefore, a strong case to reinforce existing measurers and to intensify international co-operation when formulating a response to the problem of harmful tax practices. ${ }^{134}$

Given the geographical position of Australia we have a development modern economy, albeit tiny by world standards, surrounded by under-developed nations without sophisticated economies or taxation systems. The South Pacific nations are more than willing to indulge in little more than tax fraud and openly boast of being tax havens. The Indonesian economy is in ruins, and the few Indian Ocean nations are also happy to act as tax havens.

\footnotetext{
133 Ibid, 511.

134 Organisation for Economic Co-operation and Development Recommendations on Harmful Tax Practises (April 1999) <http://www.oecd.org//daf/fa/tax_comp/r_htp.htm> at $31^{\text {st }}$ May 2001.
} 
Australia cannot win, if the government implies harsh measures to combat evasion and avoidance, in particular amendments as proposed to prevent the use of trusts as such vehicles, then it will face pressure from the OECD. If it fails to, the surrounding economies will use the opportunity to engineer tax avoidance schemes as outlined under earlier headings. The other nations are not members of the OECD and are not subject to its rules. The nations are so poor that economic sanctions cannot be effectively applied against them as they would be grossly unfair to the struggling populations or simply of no consequence to them.

The real answer is to encourage those nations to adopt the recommendations and guidelines for dealing with harmful tax practises. The difficulty is that the professionals required to encourage and re-educate the respective governments are the very ones exploiting the existing system - the taxation professionals. Further as the income from tax haven activities is such a high proportion of their revenue other industries will have to be encouraged or established to replace them.

It is very well for Australia to be a member of the exclusive world club of the OECD with its high moral platitudes, but unless its neighbours have the same standards it is pointless, and probably foolish, to follow the OECD's wishes to the letter.

Of particular interest in this paper is the impact of recommendation 1. of the Recommendations concerning domestic legislation and practices. ${ }^{135}$ That recommendation concerns Controlled Foreign Corporations (CFC) or equivalent rules: which states 'that countries that do not have such rules consider adopting them and that countries that have such rules ensure that they apply in a fashion consistent with the desirability of curbing harmful tax practices. ${ }^{136}$ Under Australian taxation laws 'the 'attributable' income of a CFC is calculated in accordance with Div 7 of $\mathrm{X}$ (ss 381-431).

As a general rule, the 'attributable' income will be calculated as if the CFC were an Australian resident company and its attributable income were the same as its taxable income. There are, however some significant modifications to this general rule. ${ }^{137}$

The modifications generally apply to the country of origin and whether or not the income is 'tainted' income. Tainted income is determined ' . . by applying the active income test contained in $\operatorname{Div} 8$ ( $\mathrm{sec} 432-455)$. Where the active income test is failed, eg because $5 \%$ or more of the CFC's relevant total income, the attributable income of the CFC will include all the tainted income in the relevant period calculated in accordance with Div 7 of Pt X ("adjusted Tainted income": s 386). Tainted income includes passive income, tainted sales and tainted services income.' ${ }^{138}$

In broad terms unless the enterprise has earned its income through transparent and 'normal trading sources' it will be considered to be tainted and all its income will be

\footnotetext{
${ }^{135}$ Ibid.

${ }^{136}$ Ibid.

${ }^{137}$ Deutsch et al., above n 8, 1358.

${ }^{138}$ Ibid, 1358-59.
} 
assessed accordingly. If the country is listed in reg 152J of the Income Tax Regulations then the double tax agreements and the OECD rules as to foreign tax are applied, if not it will be subject to full tax in Australia whether foreign tax has been paid or not.

The implications for corporate trustees and trust income under the CFC rules are such that moving income producing activities offshore are meant to be rendered pointless. In fact the approach is perhaps naïve. The government can be assured that persons who wish to avoid tax and identification of assets and are willing to enter arrangements, such as blind trusts, are unlikely to be truthful about the sources and amounts of income in any event. If one has a tax avoidance trust set up in Vanuatu, why not earn your money any which way you can? What's wrong with drug dealing, prostitution, gambling and fraud, once the boundaries have been crossed why stop?

The complex CFC rules have surely been written by those who believe Alice is Wonderland is a documentary. 


\section{Suggested Outcomes.}

\section{"Well may they say 'God Save the Queen!', because nothing will save the Governor General!"}

( Edward Gough Whitlam 1975 upon his dismissal as Prime Minister, Parliament House Canberra; Prime Minister of Australia. 1972 - 1975, 1916 - )

Constitutionally, the Australian Federal Government does not have power to legislate with respect to Trusts other than indirectly by way of matters arising to the taxation implications. The legislative power over Trusts remains in the hands of the States. However a brief history of successive transfer of legislative power from the States to the Commonwealth government indicates that a Federal 'Trusts Act' may be inevitable.

The Labor Whitlam Government started the Federal Government down the road of 'centralisation'. The company's legislative impasse clearly demonstrates the frustration with which successive Federal Governments have been plagued. The problem began with the High Court decision in 1908 in the Huddart Parker \& Co Pty Ltd $v$ Moorhead ${ }^{139}$ case and has not yet been resolved with the introduction of uniform company's legislation despite continual attempts over ninety years.

From the outset of Federation, the Commonwealth of Australia was envisaged as a servant of the States. The enactors of the Constitution deliberately limited the powers of the Federal Government ${ }^{140}$ such that the States would retain sovereignty and control over all matters other than those specifically handed over to the Commonwealth. Clearly there were matters that in the national interest, a central authority was better able to co-ordinate. For the purposes of uniformity, defence, navigation, currency, quarantine, foreign policy and other like matters were placed in the hands of a 'central authority'.

Almost immediately clashes and faults began to appear in the intent and the legal enforcement of the Constitution. The decision of the Huddart Parker \& Co Pty Ltd $v$ Moorhead case demonstrated what can happen if rules are followed to the letter and if lawyers argue issues line-by-line and word-by-word.

The matter of the Commonwealth power to levy income tax is itself a pivotal point in Australian legal history and arguably the subject of voluminous debate. Discussion of this point is outside the scope of this paper but it is important to note briefly the essential elements by which the ITAA 1936 came into existence, its continuance and the ramifications thereof.

At the beginning of World War II when Britain, its colonies and its allies were suffering major defeats, the Federal Government persuaded the States to hand over their powers of taxation to the Commonwealth of Australia. The argument being that

\footnotetext{
139 (1908) 8 CLR 330.

${ }^{140}$ PART V-Powers of the Parliament, Commonwealth of Australia Constitution Act.
} 
if the Federal Government had to wait until the August Premiers' conference to obtain funds for defence, the Japanese will have already occupied Australia.

It was not a bad argument, as the States are forbidden under the Constitution to raise military units, ${ }^{141}$ and the Japanese Forces at that time had defeated most of South East Asia. There was a plan to abandon most of Australia and retreat behind the infamous 'Brisbane Line'. ${ }^{142}$ This meant the Northern Territory, Western Australia and most of Queensland would be abandoned to the Japanese. It is little wonder that the northern and western populations of Australia bore a great distrust of the Federal Government.

As further incentive to act quickly it was promised that the powers would be handed back 'A year and a day after the cessation of hostilities.' That never happened and successive Premiers, who feel they have been tricked, have tried unsuccessfully to regain their powers to levy their own income taxes. ${ }^{143}$

It is established that once the States hand over sovereignty or authority to the Federal Government they will never retrieve them. Much debate and many cases have been fought over the matter. That debate is also outside the scope of this paper but is mentioned in order to establish the direction that Commonwealth Legislation is likely to take.

At the core of legislative direction is the Commonwealth's new found desire to control the States absolutely. Some commentators would argue that the desire is hardly new and has existed since the 1880's. Conspiracy theorists would have us believe that the dissolution of State Governments absolutely is the ultimate aim of the Federal Government. Whatever the truth of that thought or ultimate plan, if indeed one exists, the title of Father of Australian Centralisation almost certainly goes to Edward Gough Whitlam, Prime Minister of Australian from 1972 until his dismissal on November 11th 1975.

Whitlam broke the secret of State control. He was a lawyer, as was his father. He had a deep interest in politics and was very familiar with the taxation issue in World War II. As a Flight Lieutenant with 13th Bomber Squadron RAAF, he was well aware of the impact at 'the front' and the dire consequences of failure.

It was that knowledge and awareness of the 'shortcomings' of the Constitution that brought him to the answer of the conundrum of 'how can the Commonwealth with its powers limited by the Constitution, control the States and by force if necessary?' The solution to the problem was to use the Federal constitutional powers over foreign policy. ${ }^{144}$ The Federal Government under its foreign policy powers simply executed

\footnotetext{
141 Sec 114 Commonwealth of Australia Constitution Act.

${ }^{142}$ An assertion by E J Ward a minister in Menzies Liberal Government in 1941 that if a Menzies government had remained in power it would have responded to a Japanese threat to northern Australia by withdrawing all forces to a line running approximately from Brisbane to Adelaide. Frank Crowley, (ed), A New History of Australia (1976).

143 Tax Reform and the GST: An International Perspective. Binh Tran Nam ed. (ATAX Seminar Papers, 1998).

144 Sec 51(xxix) Commonwealth of Australia Constitution Act.
} 
international agreements which became ipso facto binding on the States. World Heritage and Fishing agreements, United Nations charters and policies set the starting point for the slow but certain wresting of control from the States to the Commonwealth.

Consecutive governments were not as blatant as the Whitlam Government but none of Whitlam's agreements were ever rescinded. On other occasions the Commonwealth has resorted to stealth or outright blackmail. The population of Australia may have thought the Whitlam era was over and history would never repeat itself. History has a nasty habit of repeating itself and the Howard Government is actually succeeding in areas where Whitlam didn't venture, maybe he didn't have time.

Successes of centralisation of power by the Howard Government are typified by the issues outlined below:-

Gun control - Through the use of the 'Port Arthur Massacre' the government used the emotive opportunity to bring in uniform and 'acceptable firearms controls'. The term acceptable meant acceptable to the Commonwealth.

Many States and their populations disagreed, for example in Western Australia, which had it own effective firearms legislation, or the Northern Territory and Queensland which had none, but saw rampaging gunmen as a city problem. This was achieved as a result of the removal of the powers to raise income tax as discussed above. The States were then left at the mercy of the '. . . Commonwealth by the threat of a loss of Commonwealth grants. 145

It is alleged in 2006 that statistics of crimes involving firearms have been unaffected by the introduction of the gun control measures from the trend prior to such legislation. ${ }^{146}$ That outcome is outside the scope of this paper however the relevant element is the inevitable drift in legislative control from the States to the Commonwealth government.

Tied financial grants - The financial control over the States through the use of Section 96 of the Constitution has become a greater and greater weapon for the Commonwealth in its bid to control the States. As the power to tax is shifted from the States to the Commonwealth the States become more reliant on the benevolence of the Commonwealth for funding. Section 96 was not written with the intent that its use would ultimately serve as a weapon to destroy the States.

No one could have envisaged the transfer of taxes to the Commonwealth that has taken place over the past hundred years but that is the outcome. Section 96 has been drafted in such open terms that the Commonwealth '... may grant financial assistance

\footnotetext{
145 Binh Tran Nam, above n 128.

146 Jeanine Baker and Samara Mcphedran, 'Gun Laws and Sudden Death: Did the Australian Firearms Legislation of 1996 Make a Difference?’ ( 2006) The British Journal of Crinimology 10, 1093.
} 
to any State on such terms and conditions as Parliament thinks fit. ${ }^{147}$ Section 96 was used blatantly to force the States to comply or have funding withheld.

Native title issues - The Commonwealth does not have any authority over land administration or titling. The Commonwealth has the right to acquire land on just terms, ${ }^{148}$ or to make special laws for the people of any race. ${ }^{149}$ It does not however have the power to dictate as to the alienation, encumbrances and transfers of Crown land. That is the province of the States as ex-colonies and founding members of the Commonwealth.

Through the 1967 referendum and the Mabo legislation the Commonwealth is imposing its will on the States to accept 'Native Title'. Some States and chiefly Western Australia are opposing the Commonwealth on this issue but there is no doubt that despite all argument to the contrary, the Commonwealth will succeed. The all consuming power of Section 96 will overcome any obstacles in this regard.

Revenue and licensing of alcohol, tobacco and fuel - A clever ruse that reinforced Commonwealth powers under section 90 of the Constitution, a gain by stealth rather than an exercise of legal powers. The writer is an ex-quarantine officer of the Commonwealth Health Department and as such is aware that it was common knowledge amongst Commonwealth Quarantine and Customs officers that the control and collection of monies by the States as taxes on alcohol, fuel and tobacco was unlawful. The Constitution forbids the levying of duties by the States which is expressly a province of the Commonwealth. ${ }^{150}$

The Commonwealth by way of duties and excises taxes alcohol, tobacco and fuel. For over sixty years the States also taxed those products by way of licenses based on sales. It was a comfortable but not always popular arrangement. Though many lawmakers and enforcers knew of the illegality, all chose to ignore it as it gave the States a degree of financial independence.

In 1994 and 1995 two duty free store owners in New South Wales, went out of business. The matter would have achieved no further significance had it been left to lie at that. However a curious legal challenge was to unfold. For some unknown reason a pilot was arrested for 'smuggling' tobacco from Norfolk Island to New South Wales. The 'smuggling' practice was so well organised that purpose-built transport aircraft were used for the regular deliveries.

That Customs became involved in the incident is mystifying as the practice had existed for many years. The owners of the aircraft successfully defended the charge as the tobacco was simply being transported between States and not imported into

\footnotetext{
${ }^{147}$ Sec 96 Commonwealth of Australia Constitution Act.

${ }^{148}$ Sec 51 (xxxi) Commonwealth of Australia Constitution Act.

${ }^{149}$ Sec 51 (xxvi) Commonwealth of Australia Constitution Act.

150 Sec 90 Commonwealth of Australia Constitution Act.
} 
Australia for the first time. That the complex system of importation and transportation was in place to avoid duty is irrelevant, the practice was lawful.

By coincidence, the owners of two duty free stores became embroiled in an action with the New South Wales government over the State levies by way of licensing. Legal representatives for the parties became aware of the importation case and took action in the High Court to have the convictions for the breaches of the Business Franchise Licenses (Tobacco) Act 1987 (NSW). Though the verdict was contrary to precedents set in Dickenson's Arcade Pty Ltd v Tasmania (1974); Dennis Hotels Pty Ltd v Victoria (1960); Philip Morris Ltd v Comr of Business Franchises (Vic) (1989); Capital Duplicators Pty Ltd v Australian Capital Territory (No2) (1993), ${ }^{151}$ it was held that the State could not impose such levies and that they constituted an excise provided by $\mathrm{S} 90$ of the Constitution. ${ }^{152}$

The difference being the manner in which the licenses had been based, in New South Wales the fee was based entirely on the total value of sales rather than a set license fee basis and therefore found to be a tax. The only action the New South Wales government had to take was to let the action stand ignore the lost revenue and reset its licensing system back to levels successfully held in the Dickensons and other cases.

There the matter may have lay undisturbed for another sixty years but in an interesting political move the Howard, Liberal Government encouraged the Carr, Labor Government to allow the matter to go before the full bench of the High Court even though the plaintiffs' summons for reference to the Full Court had been dismissed by Kirby J.

The Howard Government even financed the legal challenge as under S 96 of the Constitution the Federal Government can grant financial assistance as it thinks fit. Surely the Carr Government should have been aware of 'Greeks Bearing Gifts'. The outcome was obvious to even the most inexperienced of constitutional law students. The Carr Government was soundly beaten and the State taxation issue sent into disarray.

The Howard Government enacted legislation to tax alcohol, tobacco and fuel to provide collections through Federal treasury. The guise is that the tax will be collected on behalf of the States. In fact the States were collecting their own revenue and then became even more dependant on the benevolences of the Federal Government and S 96.

The reader may well wonder what those examples have to do with the future legislation of Trusts. All of the foregoing cases are examples of deliberate and progressive moves to shift control and sovereignty from States to the Commonwealth. By concentrating on one area and then the next, the Commonwealth has managed to extend its control and influence way beyond those powers prescribed in the Constitution.

\footnotetext{
151 Dickenson's Arcade Pty Ltd v Tasmania (1974) 130 CLR 177; Dennis Hotels Pty Ltd v Victoria (1960) 104 CLR 529; Philip Morris Ltd v Comr of Business Franchises (Vic) (1989) 167 CLR 399; Capital Duplicators Pty Ltd v Australian Capital Territory (No2) (1993) 178 CLR 561; 27 ATR 1.

${ }^{152}$ Ngo Ngo Ha \& Ano v State of New South Wales (1996) High Court of Australia Kirby J.
} 
Many of the above events and other political moves, culminating in the introduction of the GST legislation, will be the final nail in the States' coffins. Without an independent source of revenue the States are now at the mercy of the Commonwealth. The GST revenue - sharing arrangement with the States is by no means final and binding.

The overwhelming power of S 96 can be used at any time to counter any moves of financial independence and GST rates can be altered. The disparity of fuel pricing between the States particularly that of Western Australia to Queensland is a clear indicator that the States must comply with Federal wishes if they are to satisfactorily finance their maintenance and construction projects.

On the other hand if the Western Australian and Queensland 2001 election results can be used as a yardstick, the electorate will have their revenge at the forthcoming Federal election. Australia may not be a true democracy in that the choice of governing group is limited to one of two political parties. The Howard government can take little solace from the alternative being the relatively discredited Labor Party. The Liberal party will not be forming the governing party after 2001.

The authority over Trusts is currently in the hands of the State, but once the new entity taxing legislation is enacted, it will only be a matter of time before power over Trusts is handed over to the Commonwealth, as a matter of uniformity, convenience or duplicity of powers.

That the States cannot wrest back powers granted to the Commonwealth is an historical fact. Interestingly the Western Australian experience demonstrates that once Federation was achieved, and the Constitution enacted, the option of withdrawing from the Commonwealth has also been closed to the States. ${ }^{153}$

Historically, there is no doubt that the Howard Government will meet its demise at the very next Federal election. ${ }^{\dagger}$ There is also no doubt the successive Federal Governments will not reverse the trend towards centralisation. The move to entity taxation will eventually see the demise of the Trust, an institution that survived a thousand years are was one of the pinnacles of British law.

Trusts may continue to be used for some of the purposes originally conceived that of the dispersal of estates and the like, but as a taxation vehicle the days of the Trust are all but over. The writer predicts that eventually Commonwealth legislation will supersede the State legislation relating to Trusts.

153 On April $8^{\text {th }}$ 1933, Western Australians voted overwhelmingly in favour of withdrawing from the Federation. Western Australians put their decision to the British Parliament which had enacted the legislation, and jurisdiction to repeal it. The British refused to do so on the grounds that it could only act with the approval of the Australian Parliament. The decision, while of great security to the sovereignty of the Commonwealth, creates the conundrum that States may join the Commonwealth of their own fruition but require the approval of the Commonwealth to leave it. Given that no such approval will ever be given, powers granted to the Commonwealth can never be regained and seccession is not an option. Frank Crowley, (ed), A New History of Australia (1976). 
The effect of centralised legislation will be that trust legislation will more closely resemble current New South Wales and Victorian legislation than Western Australian legislation. Past experience and historical fact dictate that the majority of Parliamentarians are influenced by New South Wales and Victoria as they are the main population bases of Australian Society.

The legal attitudes of the Federal Government tend to reflect those facts rather than the desire to seek more acceptable alternatives. The fears held by the smaller States that Federalisation would eventually come to mean domination by New South Wales and Victoria will become a reality. It is suggested that the prudent practitioner begin studying New South Welsh and Victorian legislation if he/she is to remain conversant with trust legislation.

It is also likely that the changes to the taxation of trusts will eventually render them to antiquity for business purposes.

Many foreign uses of trusts exist and are formed purely for use as tax avoidance vehicles. These foreign trusts are widely promoted by newly formed 'Tax Havens'. Many of these are ex-British protectorates or colonies such as Vanuatu, the Cook Islands and the British Virgin Islands. These countries promote tax avoidance as a commercial enterprise and have legislated accordingly. The promotion as use of such trusts is becoming more and more prevalent as the use of the Internet and e-commerce grow with the ever expanding use of computer technology.

Such trusts are mentioned as alternative future directions of trust law in an international sense, the study of which is extensive and outside the scope of this paper. 


\section{Acknowledgements and References.}

\section{Articles/Books/Reports}

Baker, Jeanine and Mcphedran, Samara, 'Gun Laws and Sudden Death: Did the Australian Firearms Legislation of 1996 Make a Difference?'(2006) The British Journal of Crinimology 10, 1093.

Barrett, Lindsay, Chartered Accountant Article - Money Matters Island Spirit; Air Vanuatu Inflight Magazine Pacificads Port Villa, Vanuatu Issue 132001.

Carmody, Michael, 'Future Directions in Tax Administration (A Relationship of Mutual Dependency)' (Speech delivered at the National Institute of Accountants, WA division, Perth, 17 June 2003)

Cooper, Graeme S, and Wolfers, Lachlan R, Cooper's TLIP Capital Gains Tax Australian Tax Practice. Sydney. 1999.

Crowley, Frank (ed), A New History of Australia (1976).

Deutsch, Robert L et al, Australian Tax Handbook 2000 (2000).

de Wijn, John, 'Trusts Revisited' (Paper presented at the Taxation Institute of Australia $14^{\text {th }}$ National Tax Intensive Retreat, Noosa, $23^{\text {rd }}$ November 2006).

Fullarton, Alexander R, International Aspects of the Australian Goods and Services Tax (GST) (paper PGrad Dip, Curtin University, 2000).

Gaylard, Simon, Chartered Accountant Article - Trust Busters, (Taxation in Australia, Journal Taxation Institute of Australia, May 1998) 32.

Hodgson, Helen, A Prospect Intelligence Report: Law and Taxation of Trusts (1996).

Meagher, R P and Gummow, W M C, Jacobs Law of Trusts in Australia (1997).

Tran Nam, Binh (ed), State Perspective on Tax Reform; Tax Reform and the GST.. (ATAX Seminar Papers, 1998).

Woellner, Robin et al, 1997 Australian Taxation Law 7th ed. (1997).

\section{Case Law}

Aberdeen Railway Co. v Blaikie Bros (1843-60) All E.R. 249.

Bannister v Bannister [1948] 2 All E.R. 133.

Bakerv Archer-Shee [1927] AC 844.

Capital Duplicators Pty Ltdv Australian Capital Territory (No2) (1993) 178 CLR 561; 27 ATR 1. 
Chan v Zacharia (1984) 154 C.L.R. 178.

Charles v Federal Commissioner of Taxation (1954) 90 CLR 598 at 609.

Corin v Patton (1990) 169 CLR.

Dennis Hotels Pty Ltd v Victoria (1960) 104 CLR 529.

Dickenson's Arcade Pty Ltd v Tasmania (1974) 130 CLR 177.

Federal Commissioner of Taxation v Gulland

Federal Commissioner of Taxation v. Phillips (1978) 78 ATC 436.

Halloran v Minister Administering National Parks \& Wildlife Act 1974 [2006] HCA 3.

Huddart Parker \& Co Pty Ltd v Moorhead(1908) 8 CLR 330.

Keech v Snadford (1726) 2 Eq Cas Abr 741; 25 ER 223.

Income Tax Special Commissioners v Pensel [1891] A.C. 531.

Ngo Ngo Ha \& Ano v State of New South Wales (1996).

Philip Morris Ltd v Comr of Business Franchises (Vic) (1989) 167 CLR 399.

Pincus v FCT (1985) 17 ATR 1

Tindal v FC of T(1946) 72 CLR 608; 8ATD 152.

Tupicoff v FCT (1984) 15 ATR 1262

Watson v FCT

\section{Legislation}

Business Franchise Licenses (Tobacco) Act 1987 (NSW).

Commonwealth Of Australia Constitution Act 1900 as altered 1977.

Mutual Assistance in Criminal Matters Act (1990) (Vanuatu).

Partnership Act 1895 (WA).

Property Law Act 1969 (WA).

Serious Offences (Confiscation of Proceeds) Act (1990) (Vanuatu). 
Statute of Uses (1536) 27 Statutes 294.

Statute of Charitable Uses 1601.

Transfer of Land Act 1893-1972 (WA).

Income Tax Assessment Act (1936) (Cth).

\section{Treaties}

\section{Other Sources}

European Templar Research Network A Brief History of the Knights Templar $<$ http://www.euroknightstemplar.org/history.htm > at $15^{\text {th }}$ May 2001.

A Financial Centre Synopsis of the Republic of Vanuatu BDO International B.V. Chartered Accountants \& Business Advisers, Lini Highway, Port Villa, Vanuatu Jan 2001.

Collier's Encyclopedia Vol. 22 Macmillan Educational Company. New York. 1990

Ogden, Michael R, Ph. D. University of Hawaii Republic of Vanuatu; World Encyclopedia of Political Systems, 3rd ed. New York

$<$ http://www2.hawaii.edu/ ogden/piir/pacific/vanuatu.html $>$.

Ralph, John T, Allert, Rick and Joss, Robert, Review of Business Taxation (July 1999) <http://www.rbt.treasury.gov.au/paper4> at 14th April 2001.

Tax Reform and the GST: An International Perspective. Binh Tran Nam ed. (ATAX Seminar Papers, 1998).

Webster's New Twentieth Century Dictionary of the English Language unabridged 2nd ed. The World Publishing Company; Cleveland and New York. 1956. 


\section{Endnote}

Fullarton Coat of Arms, Sept of the Clan Stewart, the motto reads - Light in the Darkness.

The three red otter heads on a white background represent purity and sacrifice. The Fullartons are fowlers, hunters of eating birds, hence the three otters. In Gaelic the name is Foulertoun. The otter is unique to the Fullartons although the Mc Beths have an otter at the head of their coat of arms. Other families of fowlers are represented by gulls or other fowl such as geese. The otter is a placid creature known for its fierce defence of its home. The award was apparently granted by the Pope following the Fullartons fierce defence of a Christian monastery set up near their home in Troon Scotland in 796.

Though sold to an English peer in 1805 the Fullartons continue to occupy Troon and the peer has never claimed his ownership. The Fullartons have a long and proud history of engineering, military, administration and scholastic achievement. They have befriended, but never have been blood relative of any King, nor are they blood relatives of the Stewarts who are Norman. Their tartan is that of a 'Black' Stewart which shows they are a separate part of sept of the Clan of Stewart.

The Fullartons are one of the few remaining families of true Scot who occupied Scotland prior to the arrival of the Romans in England. It is believed by some that they are descendents of Phoenician traders who sailed to Scotland as far back as 3000 BC. 
' Since this paper was first written the Howard government faced a general election and was not defeated as predicted. Voters ignored the impact of changes on the Australian taxation system and were distracted by other world events. These included the terrorist strikes and the destruction of the World Trade Centre in New York, War in Afghanistan and the racially focussed refugee crisis focussed on an event termed the Tampa affair.

The Howard lead Liberal Party successfully campaigned on foreign threats and distracted the Australian voters from the GST debacle. In almost stage managed art Australians followed the distractions which were so skilfully employed by Sir Robert Menzies of which John W Howard is an admirer and follower. He is indeed a most remarkable Prime Minister. 